\title{
The Distribution of Calcium Buffering Proteins in the Turtle Cochlea
}

\author{
Carole M. Hackney, ${ }^{1}$ Shanthini Mahendrasingam, ${ }^{1}$ Eugenia M. C. Jones, ${ }^{2}$ and Robert Fettiplace ${ }^{2}$ \\ ${ }^{1}$ MacKay Institute of Communication and Neuroscience, School of Life Sciences, Keele University, Keele, Staffordshire ST5 5BG, United Kingdom, and \\ ${ }^{2}$ Department of Physiology, University of Wisconsin Medical School, Madison, Wisconsin 53706
}

\begin{abstract}
Hair cells of the inner ear contain high concentrations of calcium-binding proteins that limit calcium signals and prevent cross talk between different signaling pathways during auditory transduction. Using light microscope immunofluorescence and post-embedding immunogold labeling in the electron microscope, we characterized the distribution of three calcium-buffering proteins in the turtle cochlea. Both calbindin-D28k and parvalbumin- $\beta$ were confined to hair cells in which they showed a similar distribution, whereas calretinin was present mainly in hair-cell nuclei but also occurred in supporting cells and nerve fibers. The hair-cell concentration of calbindin-D28k but not of parvalbumin- $\beta$ increased from the low- to high-frequency end of the cochlea. Calibration against standards containing known amounts of calcium-buffering protein processed in the same fluid drop as the cochlear sections gave cytoplasmic concentrations of calbindin-D28k as $0.13-0.63 \mathrm{~mm}$ and parvalbumin- $\beta$ as $\sim 0.25 \mathrm{~mm}$, but calretinin was an order of magnitude less. Total amount of $\mathrm{Ca}^{2+}$-binding sites on the proteins is at least $1.0 \mathrm{~mm}$ in low-frequency hair cells and $3.0 \mathrm{~mm}$ in high-frequency cells. Reverse transcription-PCR showed that mRNA for all three proteins was expressed in turtle hair cells. We suggest that calbindin-D28k and parvalbumin- $\beta$ may serve as endogenous mobile calcium buffers, but the predominantly nuclear location of calretinin argues for another role in calcium signaling. The results support conclusions from electrophysiological measurements that millimolar concentrations of endogenous calcium buffers are present in turtle hair cells. Parvalbumin- $\beta$ was also found in both inner and outer hair cells of the guinea pig cochlea.
\end{abstract}

Key words: cochlea; calcium buffers; calbindin-D28k; calretinin; hair cells; immunocytochemistry; post-embedding labeling; parvalbumin

\section{Introduction}

Cytoplasmic calcium regulates multiple fast events related to transduction in auditory hair cells, including adaptation of mechanotransducer channels (Assad et al., 1989; Crawford et al., 1989), gating of $\mathrm{Ca}^{2+}$-activated $\mathrm{K}^{+}$channels (Art and Fettiplace, 1987; Roberts et al., 1990), and neurotransmitter release (Parsons et al., 1994; Moser and Beutner, 2000). Each calcium-dependent process is sensitive to the amount of calcium buffer (e.g., BAPTA) in the intracellular solution. Comparison of results with exogenous buffers with those using perforated-patch recordings, in which soluble proteins are not eluted from the cytoplasm, was used to estimate the concentration of the native mobile calcium buffer of the hair cell (Roberts 1993; Tucker and Fettiplace, 1996). In turtle auditory hair cells, this buffer is equivalent to 0.1-0.4 mM BAPTA and has similar concentrations in the hair bundle and cell body but changes with the characteristic frequency (CF) of the cell (Ricci et al., 1998, 2000). The variation probably reflects differences in the size of the $\mathrm{Ca}^{2+}$ influx via mechanotransducer or voltage-dependent $\mathrm{Ca}^{2+}$ channels, which both increase in number with CF (Ricci and Fettiplace, 1997;

Received Nov. 14, 2002; revised March 10, 2003; accepted March 24, 2003.

This work was supported by grants from the Wellcome Trust (C.M.H.) and the Steenbock fund of the University of Wisconsin and National Institutes on Deafness and Other Communicative Disorders Grant R01 DC 01362 (R.F.). We thank Mary Reynolds for much excellent technical assistance. We are also grateful to Stefan Heller and Jim Hudspeth for the gifts of bullfrog parvalbumin- 3 and its antibody.

Correspondence should be addressed to Robert Fettiplace, 185 Medical Sciences Building, 1300 University Avenue, Madison, WI 53706. E-mail: fettiplace@physiology.wisc.edu.

Copyright $\odot 2003$ Society for Neuroscience $\quad$ 0270-6474/03/234577-13\$15.00/0
Ricci et al., 2000). One function of the mobile buffer may be to limit the spread of $\mathrm{Ca}^{2+}$ and prevent cross talk between different signaling pathways (Roberts, 1994; Hall et al., 1997).

Although the identity of the endogenous calcium buffer in turtle hair cells is unknown, several proteins thought to function as calcium buffers have been found in the inner ears of other vertebrates. These include calbindin-D28k (Dechesne and Thomasset, 1988; Oberholtzer et al., 1988), calretinin (Rogers 1989; Dechesne et al., 1991), and parvalbumin, which occurs in two forms: parvalbumin- $\alpha$ (Eybalin and Ripoll, 1990) and parvalbumin- $\beta$ or oncomodulin (Sakaguchi et al., 1998; Heller et al., 2002). Each protein has been reported to show a unique pattern of expression (Pack and Slepecky, 1995; Baird et al., 1997; Edmonds et al., 2000), often restricted to one region of the haircell epithelium or one part of the cell. No ultrastructural postembedding labeling is available to confirm the subcellular distribution for these proteins.

Electrophysiological measurements on turtle hair cells (Ricci et al., 1998) indicate that the native calcium buffer, if it were calbindin-D28k, could have a concentration of $0.5-2 \mathrm{~mm}$. These values were derived from equivalent BAPTA concentrations (0.1-0.4 mM) using simulations of stereociliary calcium gradients, assuming that calbindin-D28k has four $\mathrm{Ca}^{2+}$ binding sites per molecule compared with one in BAPTA but binds $\mathrm{Ca}^{2+} 25$ times more slowly. Immunocytochemical data on the distribution of calcium-buffering proteins have not been quantified. However, biochemical analysis of the chick cochlea gave a calbindin-D28k concentration of $\sim 1 \mathrm{~mm}$ (Oberholtzer et al., 
1988). By quantifying immunoblots, the concentration of parvalbumin-3 in one type of frog saccular hair cell was estimated as $3 \mathrm{~mm}$, suggesting that it is the dominant mobile buffer in these cells (Heller et al., 2002). In the present study, quantitative immunogold labeling has been used to compare the distributions of calbindin, calretinin, and parvalbumin along the turtle cochlea and determine the relative abundance to assess their role in cytoplasmic calcium buffering.

\section{Materials and Methods}

Antibodies and purified proteins. Primary antibodies against the calciumbinding proteins calbindin, calretinin, and parvalbumin were used in this study. These included commercially available polyclonal antibodies to recombinant rat calbindin-D28k and parvalbumin- $\alpha$ (SWant, Bellinzona, Switzerland), a monoclonal antibody to human calretinin-22k (SWant), and a polyclonal antibody to recombinant rat calretinin (Chemicon, Temecula, CA) that recognizes both the calcium-bound and calcium-unbound versions of calretinin in immunoblots. A polyclonal antibody to recombinant bullfrog parvalbumin-3 (GenBank accession number AALO9922; Heller et al., 2002) was kindly provided by Dr. S. Heller (Eaton Peabody Laboratory and Department of Otolaryngology, Massachusetts General Hospital, Boston, MA).

The secondary antibodies used for immunofluorescence labeling were goat anti-rabbit IgG-FITC conjugate or goat anti-mouse- tetramethylrhodamine isothiocyanate (TRITC) conjugate (Sigma, Poole, UK). The secondary antibodies used for transmission electron microscopy were 15 $\mathrm{nm}$ colloidal gold-conjugated anti-rabbit and anti-mouse IgGs (British Biocell, Cardiff, UK). Purified proteins were used for preadsorption controls. These included recombinant rat calbindin-D28k, human calretinin (6-His-CR), and rat parvalbumin- $\alpha$ (SWant) and bullfrog parvalbumin-3 provided by Dr. Heller. The "parvalbumin-3" nomenclature reflects the fact that the latter protein most closely resembles CPV3, one of three parvalbumin-like proteins first isolated from chick (Hapak et al., 1994). In other species, only two parvalbumins, parvalbumin- $\alpha$ and parvalbumin- $\beta$, have been found so far (for review, see Pauls et al., 1996). Parvalbumin- $\alpha$ is typically expressed in fast skeletal muscle and in some GABAergic neurons. In mammals, parvalbumin- $\beta$ has been found in preimplantation embryos and in tumors from a variety of origins (hence the term "oncomodulin"), as well as in the mammalian cochlea. Chicken CPV3 displays strong sequence similarity to oncomodulin and is thought to belong to the parvalbumin- $\beta$ family (Hapak et al., 1994). Turtle muscle is unusual in containing a parvalbumin belonging to the $\beta$ sublineage (Maeda et al., 1984).

Animals. Most of the turtle cochleae (10) used in this study were obtained and prepared as for related physiological studies (Ricci and Fettiplace, 1997). Red-eared turtles (Trachemys scripta elegans; carapace length of 100-125 mm) were decapitated, the head was split sagittally, and the otic capsules were exposed using procedures approved by the Animal Care Committee at the University of Wisconsin (protocol number A3368-01). The otic capsule was opened, and the cochlea and lagena were dissected out and incubated in saline (in mM: $125 \mathrm{NaCl}, 4 \mathrm{KCl}, 2.8$ $\mathrm{CaCl}_{2}, 2.2 \mathrm{MgCl}_{2}, 2 \mathrm{Na}$ pyruvate, 8 glucose, and $10 \mathrm{Na}$-HEPES, pH 7.6) containing up to $0.06 \mathrm{mg} / \mathrm{ml}$ protease (type XXIV; Sigma, St. Louis, MO) for $20 \mathrm{~min}$. The tectorial membrane was then removed to expose the hair bundles, the point at which physiological recordings are normally made from hair cells. Here, the preparations were instead placed in $4 \%$ paraformaldehyde in $0.1 \mathrm{M}$ sodium phosphate buffer (PB), $\mathrm{pH} 7.4$, for $2 \mathrm{hr}$ at room temperature. They were then stored in $0.4 \%$ paraformaldehyde-PB at $4^{\circ} \mathrm{C}$ until being processed further for either light microscope immunohistochemistry or for transmission electron microscopy. Four additional cochleae were prepared using a more rapid fixation technique to improve the preservation of the afferent nerve terminals at the bases of the hair cells. For this, two turtles were decapitated, the otic capsules were opened, and the half-head was immediately perfused with fixative. After being immersed in fixative for $2 \mathrm{hr}$, the half-head was washed in phosphate buffer, and the cochlea was dissected out as before.

Parvalbumin-3 distribution was also characterized in mammalian cochlear hair cells. These experiments were performed on sections of guinea pig cochleae, prepared as described previously (Mahendrasingam et al., 1997). A guinea pig was killed with an overdose of sodium pentobarbital (Pentoject; $100 \mathrm{mg} / \mathrm{kg}$, i.p.) and decapitated, the bulla was removed, and the cochleae were exposed. The cochleae were perfused with $4 \%$ paraformaldehyde in PB via a small hole in the apex and openings in the round and oval window at the base. They were then immersed in fixative for $2 \mathrm{hr}$ and washed in PBS, and the bone was partially removed and dehydrated in a graded series of ethanols. They were incubated in pure LR-White resin for $24 \mathrm{hr}$ and then placed in a gelatin capsule for polymerization of the resin at $50^{\circ} \mathrm{C}$ for $24 \mathrm{hr}$. Segments of the organ of Corti were obtained by microslicing the embedded cochlea using a diamond bladed circular saw, and ultrathin sections were cut onto nickel grids and processed as for the turtle (see below).

Light microscope immunohistochemistry. Fixed turtle cochleae were washed in $0.1 \mathrm{M}$ PBS, $\mathrm{pH} 7.4$, permeabilized with $0.5 \%$ Triton X-100 in PBS for 30 min, washed in PBS, blocked in 10\% goat serum (GS) in PBS for $30 \mathrm{~min}$, and incubated in primary antibody overnight at $4^{\circ} \mathrm{C}$. The polyclonal anti-calbindin-D28k and monoclonal and polyclonal anticalretinin antibodies were diluted 1:500, and the polyclonal antiparvalbumin-3 antibody was diluted 1:10,000 in 1\% bovine serum albumin (BSA) in PBS. They were then washed in 1\% BSA-PBS, incubated in either goat anti-mouse or anti-rabbit IgG-FITC conjugate diluted (1:20) in $1 \%$ BSA-PBS for $2 \mathrm{hr}$, washed in 1\% BSA-PBS and in PBS, and mounted in PBS on a cavity slide. Cochlear whole mounts were examined under a $60 \times$ objective [Nikon (Tokyo, Japan) ELWD Planfluor; numerical aperture, 0.7] using a Bio-Rad (Hemel Hempstead, UK) MRC$1024 \mathrm{ES}$ laser scanning microscope system operating in confocal mode. A series of z-sections was acquired at 2 or $4 \mu \mathrm{m}$ intervals and superimposed to generate a three-dimensional image stack.

To demonstrate the codistribution of two proteins, double-labeling experiments were performed using two separate methods. To determine whether calbindin-D28k and calretinin were colocalized, the cochlea was incubated simultaneously in rabbit polyclonal anti-calbindin-D28k and mouse monoclonal anti-calretinin after the appropriate permeabilization and blocking steps. It was then washed in 1\% BSA-PBS, incubated in goat anti-rabbit IgG-FITC and anti-mouse IgG-TRITC diluted (1:20) in $1 \%$ BSA-PBS for $2 \mathrm{hr}$, and washed in 1\% BSA-PBS before viewing. To examine colocalization of calbindin-D28k and parvalbumin-3, a different approach was used because both antibodies were polyclonals made in rabbit. In this case, the cochlea was prepared as for a single antibody, either calbindin-D28k or parvalbumin-3, and incubated in anti-rabbit IgG-FITC secondary antibody; the tissue was then refixed in $4 \%$ paraformaldehyde in PB for $1 \mathrm{hr}$, washed thoroughly in PBS, blocked, incubated in the other primary antibody, and labeled with anti-rabbit IgG-TRITC secondary. To eliminate differential effects caused by refixation, both experimental combinations were performed in which the tissue was treated first with anti-calbindin-D28k and then with antiparvalbumin-3, or first with anti-parvalbumin-3 and then with anti-calbindin-D28k.

Electron microscopy and immunogold labeling. Fixed turtle cochleae were washed in $0.1 \mathrm{M}$ phosphate buffer, $\mathrm{pH} 7.4$, dehydrated in a graded series of ethanols (70\%, $15 \mathrm{~min} ; 80 \%, 15 \mathrm{~min} ; 90 \%, 15 \mathrm{~min}$; and 100\%, 15 min for two times), and infiltrated with LR-White resin (Agar Scientific, Stansted, UK) at room temperature for $24 \mathrm{hr}$ (four changes). Finally, the cochleae were placed in pure resin in gelatin capsules that was polymerized at $50^{\circ} \mathrm{C}$ for $24 \mathrm{hr}$. Ultrathin $(120 \mathrm{~nm})$ longitudinal sections of the cochleae were cut on a Leica (Milton Keynes, UK) Ultracut ultramicrotome and collected on 200-mesh nickel grids. The grids were washed in 0.05 м Tris-buffered saline (TBS), $\mathrm{pH} 7.4$, and nonspecific protein binding was blocked using $20 \%$ GS in TBS for $30 \mathrm{~min}$. They were then incubated overnight at $4^{\circ} \mathrm{C}$ in the appropriate primary antibody diluted in TBS containing 1\% BSA as follows: polyclonal anti-calbindin-D28k, monoclonal anti-calretinin, and polyclonal anti-calretinin (1:500), and polyclonal anti-parvalbumin-3 (1:5000-1:10,000). This was followed by washing in $1 \%$ BSA-TBS and incubation in either goat anti-mouse IgG or anti-rabbit IgG conjugated to $15 \mathrm{~nm}$ gold diluted 1:20 in 1\% BSA-TBS for $1 \mathrm{hr}$ at room temperature. The grids were washed again in TBS, followed by distilled water. The sections were stained using $2 \%$ aqueous uranyl acetate for $20 \mathrm{~min}$, followed by lead citrate for $2 \mathrm{~min}$ and 
examined using a Jeol-100CX transmission electron microscope (Jeol, Welwyn Garden City, UK) operated at an accelerating voltage of $100 \mathrm{kV}$.

Analysis of immunogold labeling densities. To determine the density of gold labeling in different compartments of the cells along the length of cochlea [from the high-frequency (HF) region to the low-frequency (LF) region], micrographs were taken of the entire length of the epithelium $(1000 \times)$, and a montage was constructed. A random sampling method was then used to count the number of gold particles in the different tissue compartments. To count the number of gold particles in the cytoplasm of hair cells and supporting cells, mitochondria-free areas were randomly selected at low magnification $(4800 \times)$ in which the gold particles were not visible. The magnification was then increased $(19,000-48,000 \times)$ so that gold particles could be counted within the same field of view on the transmission electron microscope. The same method was used to determine the densities of gold particles in the nucleus of hair cells. Scatter plots of gold particle densities expressed as number of particles per square micrometer were constructed using the positions that were mapped for sampling on the montage along the length of the cochlea to provide the distance and the counts of gold labeling.

Preadsorption controls. For negative controls for the antibodies to calbindin-D28k and calretinin, $1 \mu \mathrm{l}(1.43 \mu \mathrm{g})$ of the reconstituted purified protein was added to $143 \mu \mathrm{l}$ of the appropriate antibody solution (1:500 dilution), mixed thoroughly, and incubated for $6 \mathrm{hr}$ at $4^{\circ} \mathrm{C}$ on a rotator. The procedure and concentrations used were as specified by the protocol of the manufacturer SWant for adsorption in their product description. For bullfrog parvalbumin-3, $10 \mu \mathrm{l}(13 \mu \mathrm{g})$ of parvalbumin-3 was added to $130 \mu$ l of diluted (1:5000) anti-parvalbumin- 3 solution. As a negative control for parvalbumin- $\alpha, 1 \mu \mathrm{l}(1 \mu \mathrm{g})$ of recombinant rat muscle parvalbumin (parvalbumin- $\alpha$ ) was added to $1 \mathrm{ml}$ of diluted ( 1 : 5000) anti-parvalbumin-3 solution. In each case, the preadsorbed antibody solution was centrifuged for $10 \mathrm{~min}$, and the supernatant was used in parallel with the unadsorbed primary antibody. The primary antibody solution was treated in exactly the same way (including centrifugation) as the preadsorbed antibody solution.

Determination of hair-cell protein concentration. To establish the concentration range of calbindin, calretinin, and parvalbumin in hair cells, a calibration procedure was used similar to that devised previously for determining glutamate concentrations in nerve terminals (StormMathisen and Ottersen, 1990). A solution of each protein in 10\% BSA in $4 \%$ paraformaldehyde in $\mathrm{PB}$ was made, and the mixture was solidified into a gel by the addition of $0.1 \%$ glutaraldehyde. A $1-2 \mathrm{~mm}$ block of each gel was dehydrated and embedded in resin in the same manner as the tissue prepared for transmission electron microscopy to provide a protein standard. Ultrathin sections were then cut onto nickel grids from the standard and immunolabeled with the relevant primary antibody and gold-conjugated secondary antibody under the same conditions and in parallel with the labeling of a cochlear sample. To ensure identical labeling conditions, both the standard and cochlear sections were processed at the same time and in the same fluid drop. In the first instance, to conserve scarce protein, gels were made with protein concentrations of 1-5 $\mu \mathrm{M}$. Within this range, the gold particle count over the standard was proportional to protein concentration. For calbindin-D28k, a later calibration was performed with a gel containing $225 \mu \mathrm{M}$ of the protein. To determine the effect of the $0.1 \%$ glutaraldehyde used to produce the standards on the efficiency of the antibody labeling, a turtle cochlea fixed in $4 \%$ paraformaldehyde in the same manner as those for the rest of the study was postfixed with $0.1 \%$ glutaraldehyde. Sections from this cochlea were then immunolabeled for the relevant calcium-binding protein at the same time as those from a specimen that had been fixed using only paraformaldehyde. Immunogold counts were made from hair cells at similar positions along the length of the cochlea, and the difference in the immunolabeling level was calculated. With both calbindin-D28k and parvalbumin-3, there was $\sim 2.5$-fold reduction $(2.45 \pm 0.21 ; n=3)$ in label caused by glutaraldehyde. The effects of glutaraldehyde on calretinin labeling was not determined because of the small number of counts per cell but was assumed to be the same as that for calbindin-D28k.

Immunoblots. Samples of fresh turtle hindbrain and cerebellum and muscle were homogenized in HEPES-EDTA buffer (in mM: $125 \mathrm{NaCl}, 1$ $\mathrm{MgCl}_{2}, 25 \mathrm{NaHEPES}, \mathrm{pH} 7.4,4 \mathrm{KCl}, 5$ glucose, and 2 NaEDTA) contain- ing protease inhibitors ( $1 \mu \mathrm{g} / \mathrm{ml}$ leupeptin and $0.5 \mu \mathrm{g} / \mathrm{ml}$ pepstatin), and the homogenate was centrifuged at $3000 \times g$ for $10 \mathrm{~min}$. The pellet was resuspended in the homogenization buffer for later use, and the supernatant was centrifuged at $35,000 \times g$ for $30 \mathrm{~min}$. The supernatant was then collected, and the pellet was rinsed twice and resuspended in homogenization buffer. The protein concentration in each of these three fractions was determined using a modified Bradford assay. Each of the protein samples was run on a $12 \%$ SDS-PAGE gel alongside recombinant calbindin-D28k and calretinin (SWant), and the gel was transferred to nitrocellulose. Twelve micrograms of total protein were loaded into each lane. Blots were blocked in 3\% BSA in TBS plus $0.05 \%$ Tween (TTBS) for $2 \mathrm{hr}$ at room temperature, followed by overnight incubation in primary antibody $(1: 1000)$ in $2 \% \mathrm{BSA}$ in TTBS at $4^{\circ} \mathrm{C}$. Blots were rinsed six times in TTBS and incubated for $1 \mathrm{hr}$ at room temperature in secondary antibody [1:50,000 HRP-conjugated goat anti-rabbit antiserum (Vector Laboratories, Burlingame, CA) in 2\% BSA in TTBS]. They were again washed six times in TTBS for $10 \mathrm{~min}$ each, and the antibody labeling was visualized using a chemiluminescent technique (Super-Signal West Pico; Pierce, Rockford, IL) according to the instructions of the manufacturer. Results with the SWant calbindin antiserum were not altered significantly by preadsorption with recombinant calretinin. The density of the bands on the gels was quantified with a GS670 Imaging Densitometer (Bio-Rad).

To obtain additional quantitative information, immunoblots were performed on turtle cochlear tissue. Turtle cochleae were dissected and trimmed to remove residual pieces of the saccule and the ampulla of the posterior semicircular canal and dissolved in $20 \mathrm{~mm} \mathrm{~PB}, \mathrm{pH}$ 7.4, containing $5 \mathrm{~mm}$ EDTA and a protease inhibitor mixture (Complete; Roche Diagnostics, Indianapolis, IN) and processed as described by Mahendrasingam et al. (1998). Tissue from seven cochleae was collected in $15 \mu \mathrm{l}$ of buffer solution, added to $15 \mu \mathrm{l}$ of sample buffer (62.5 mм Tris- $\mathrm{HCl}$, pH 6.5, with $2 \%$ SDS, 5\% mercaptoethanol, $10 \%$ glycerol, and $0.001 \%$ bromophenol blue), and heated for $3 \mathrm{~min}$ at $100^{\circ} \mathrm{C}$. Cochlear proteins were separated on a $12 \%$ polyacrylamide gel aongside recombinant calbindin-D28k, calretinin, and parvalbumin-3 and then electroblotted onto nitrocellulose. Blots were incubated with antibodies to each of the three calcium-binding proteins (1:500 for calbindin-D28k and calretinin; 1:5000 for parvalbumin-3), and bands labeled by the primary antibody were visualized using a biotin extravidin-peroxidase procedure (Sigma). For a negative control for the turtle cochlea, primary antibody was replaced with dilution buffer.

Expression of $m R N A$. For each of the calcium-binding proteins, the mRNA expression in turtle hair cells was examined using a reverse transcription (RT)-PCR technique. Degenerate primers were designed based on the sequences for chicken calbindin-D28k and calretinin and were initially used to amplify message from poly $\left(\mathrm{A}^{+}\right)$mRNA from turtle brain (Jones et al., 1998). The sequences corresponded to amino acid residues 10-15 (VEISAA) and 247-252 (KLYRAE) for calbindin-D28k and residues 7-13 (PHLHLAE) and 166-172 (NGDGKLG) for calretinin. PCR products were subcloned and then sequenced at the University of Wisconsin Biotechnology Center (Madison, WI). Turtle-specific primers for the two proteins were constructed from the nucleotide sequences derived from the brain products. The primers for calbindin-D28k were as follows: 5'GAACTTCATCCAGGAGCTTC (forward) and 5'CCATTGCCATCTTGATCATAC (reverse). The primers for calretinin were as follows: 5'CTACATTGAGGCAAGGAGCTGG (forward) and 5'GCAGCTTTGGCTCATCGTAGG (reverse).

These primers were used to amplify cDNA from hair cells isolated from the turtle cochlea as described previously (Jones et al., 1998). After an initial denaturation at $94^{\circ} \mathrm{C}$ for $120 \mathrm{sec}$, PCR conditions were as follows: 35 cycles of denaturation at $94^{\circ} \mathrm{C}$ for $45 \mathrm{sec}$, annealing at $56^{\circ} \mathrm{C}$ for 60 $\mathrm{sec}$ (calbindin-D28k) or $62^{\circ} \mathrm{C}$ for $60 \mathrm{sec}$ (calretinin), and extension at $72^{\circ} \mathrm{C}$ for $120 \mathrm{sec}$, with a final extension for $10 \mathrm{~min}$. The products obtained were of the appropriate length (351 bp for calretinin and $501 \mathrm{bp}$ for calbindin-D28k) and gave the correct banding pattern when digested with restriction enzymes (BamHI for calretinin and AflII and EarI for calbindin-D28k) and size separated with PAGE.

An amino acid (but not a nucleotide) sequence was available for muscle parvalbumin of the map turtle Graptemys geographica (Maeda et al., 
1984; Swiss pro P02614). Comparison with other parvalbumin sequences has indicated that the turtle muscle parvalbumin belongs to the $\beta$ lineage (Maeda et al., 1984). Degenerate primers were constructed on the basis of conserved regions of the aligned sequences of map turtle parvalbumin- $\beta$ and bullfrog parvalbumin-3, corresponding to amino acids 51-60 (forward) and amino acids 95-103 (reverse). The primers were as follows: 5'-GAT/CGAA/GGAT/CAAA/GTCIGGITTT/CATIGAA/GG (forward) and 5'-GA/GAAT/CTCA/GTCIACICCIATT/CTTICC (reverse).

These degenerate primers were used to amplify a $156 \mathrm{bp}$ product related to parvalbumin- $\beta$ from muscle of the red-eared turtle. The deduced amino acid sequence was as follows: DQDKSGFMEEDELQLFLQNFSSTARALTAAETKAFMAAGTDGDGDGKIGVDEF. This is identical to that portion of sequence (amino acid residues 52-103) for the map turtle parvalbumin- $\beta$. Specific primers were then built from the turtle muscle cDNA: 5'-GATGAGCTTCAGCTGTTTCTG (forward) and 5' GTCACCTGCAGCCATGAAAG (reverse).

The specific primers were used to amplify cDNA from turtle muscle, cerebellum, and hair cells. Products were size separated by agarose gel electrophoresis, blotted, and probed with ${ }^{32} \mathrm{P}$-labeled (156 bp) cDNA cloned from turtle muscle. Products of the expected $92 \mathrm{bp}$ size were seen in all three turtle tissues, indicating that the same parvalbumin- $\beta$ is expressed in brain, muscle, and hair cells.

\section{Results}

Hair-cell mRNA for calcium-binding proteins

Calbindin-D28k and calretinin were both cloned from turtle brain cDNA. For calbindin-D28k, 243 of the 263 amino acid residues were identified (GenBank accession number AF545849), giving a sequence that is $82 \%$ identical to the equivalent region in human and rat. For calretinin, amino acid residues 7-172 (of a total 269) were obtained (GenBank accession number AY150212), the sequence being $91 \%$ identical to human and rat over a region to which both monoclonal and polylconal antibodies to calretinin were made. Turtle-specific primers were then used to show that message for both calcium-binding proteins was expressed in turtle auditory hair cells. PCR products obtained from hair cells were of the expected length and gave fragments of the appropriate size when cut with restriction enzymes (see Materials and Methods). The appearance of both calcium-binding proteins in the inner ear was first shown for the chicken (Rogers, 1989). To demonstrate that the human and rat polyclonal antibodies would recognize the calciumbinding proteins in turtle, immunoblots were performed of material isolated from turtle hindbrain, which was run in parallel with the relevant recombinant proteins (Fig. 1A). Differential centrifugation of the brain tissue gave three fractions corresponding to nucleus and mitochondria, cytoplasm, and membrane. The intensity of the bands was used to show that, although a majority of the label was in the cytoplasmic fraction, a significant proportion of protein was also present in the nuclear and membrane fractions (Fig. 1A). It should be noted that densitometry of the bands on the immunoblots suggested that, at the same antibody dilution (1:1000), the calretinin antibody was approximately four times more effective than the calbindin-D28k antibody in labeling the same amount of recombinant protein.

Degenerate primers were used to isolate a partial parvalbumin- $\beta$ sequence from turtle muscle (GenBank accession number AY150848), which allowed the construction of turtlespecific primers. These primers were used to amplify a cDNA product of the correct size from turtle hair cells, and this band could be labeled with parvalbumin- $\beta$ cDNA. Thus, there is evidence for expression of all three calcium-binding proteins calbindin-D28k, calretinin, and parvalbumin in hair cells of the turtle cochlea. Immunoblots were performed using protein isolated from turtle muscle and cerebellum, which showed that the bullfrog parvalbumin-3 antibody recognized turtle proteins of
A

Brain

Calbindin

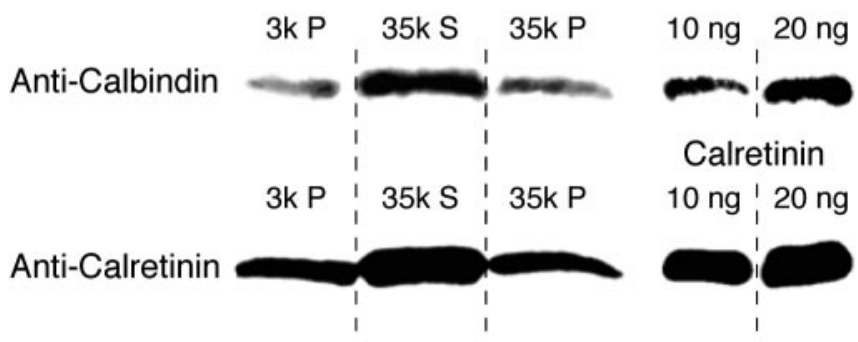

$B$

\section{Anti-Parvalbumin-3}

Muscle Brain

$15 \mathrm{kD}-$

$10 \mathrm{kD}-$

C

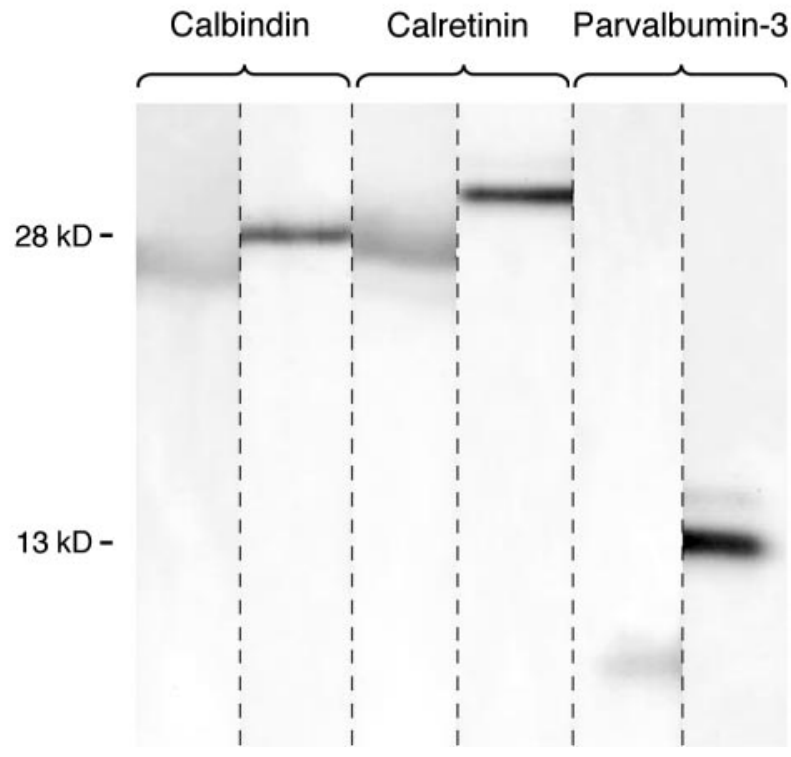

Figure 1. Immunoblots of turtle tissue with polyclonal calbindin-D28k, calretinin, and parvalbumin- 3 antibodies. $A$, Turtle hindbrain extract run alongside the respective recombinant protein on $7.5 \%$ polyacrylamide gels. The three tissue lanes correspond to different cellular fractions obtained with sequential 3000 and 35,000 - $g$ centrifugation: nucleus and mitochondria $(3,000 \times g$ pellet, $3 \mathrm{kP}$ ), diffusible cytoplasmic $(35,000 \times g$ supernatant, $35 \mathrm{k} S)$, and membrane $(35,000 \times g$ pellet, 35k P). Although for both calbindin-D28k and calretinin the largest label was in the diffusible cytoplasmic fraction, some label also occurred in the other cell fractions. $B$, Turtle muscle and hindbrain extract $(35,000 \times g$ supernatant) run on a $10-20 \%$ gradient polyacrylamide gel and labeled with antibody to parvalbumin-3. Forty times more brain protein (mostly cerebellum) was loaded on the gel compared with muscle protein. C, Turtle cochlear proteins run on a $12 \%$ polyacrylamide gel alongside calbindin-D28k, calretinin, and parvalbumin-3. For each pair of lanes, the left one contains protein from a single cochlea, and the right one contains $10 \mathrm{ng}$ of pure protein. The band for turtle parvalbumin is at $\sim 11.5$ $\mathrm{kDa}$ compared with $13 \mathrm{kDa}$ for bullfrog parvalbumin-3.

the appropriate size, $\sim 12 \mathrm{kDa}$ (Fig. $1 B$ ). This is close to the reported molecular weight of turtle parvalbumin- $\beta, 11.6 \mathrm{kDa}$ (Maeda et al., 1984).

The antibodies were also tested on immunoblots of turtle cochlear material (Fig. 1C). By comparing the intensities of the cochlear bands with the intensities of bands for the pure proteins, we were able to estimate the amount of protein present in the cochlea as $9.6 \mathrm{ng}$ for calbindin-D28k, $13.7 \mathrm{ng}$ for calretinin, and 4.9 


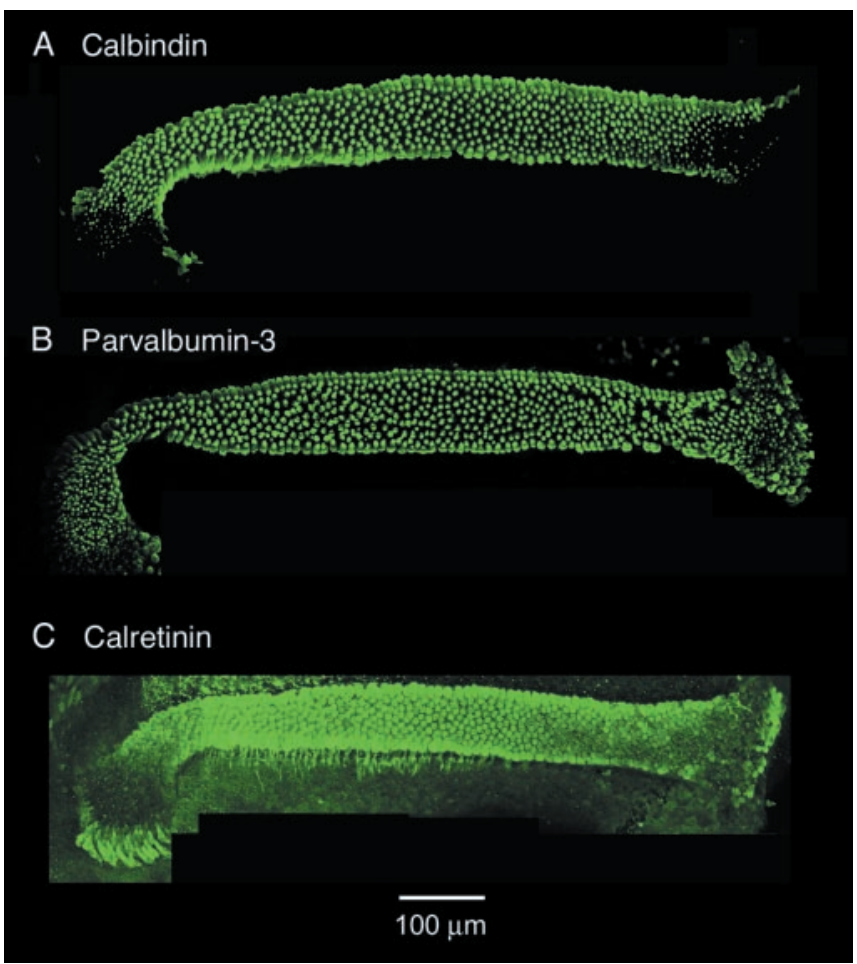

Figure 2. Immunofluorescence of turtle cochlear whole mounts labeled with antibodies to calcium-binding proteins. A, Polyclonal (SWant) calbindin-D28k. B, Polyclonal frog parvalbumin-3. C, Monoclonal (SWant) calretinin. Each whole mount is a montage of five to seven images, acquired with a $60 \times$ objective, and is oriented with the low-frequency end on the right. The hooked region of the cochlea on the left represents hair cells on the limbus that have different morphology to those on the basilar membrane (Hackney et al., 1993). Note that calbindin-D28k and parvalbumin-3 label the hair cells on basilar membrane, but calretinin labels other cell types, including the nerve fibers emanating from the papilla. For both calbindin-D28k and calretinin, the immunofluorescence intensity increases from low- to highfrequency end.

ng for parvalbumin-3. To convert these amounts to concentrations, it is necessary to assume the distribution of the protein and the size of the compartment. As will be shown in the subsequent immunohistochemistry, calbindin-D28k and parvalbumin-3 are both strictly localized to the hair cells. To obtain a hair cell protein concentration, the cochlea is assumed to comprise 1000 cylindrical hair cells 25 $\mu \mathrm{m}$ in length and $10 \mu \mathrm{m}$ in diameter (Hackney et al., 1993). These dimensions correspond to a cellular volume of $2 \mathrm{pl}$ (neglecting the stereociliary bundle), and the average protein concentrations inferred are $0.17 \mathrm{~mm}$ for calbindin-D28k and $0.2 \mathrm{~mm}$ for parvalbumin-3. Applying the same argument to calretinin implies a hair-cell concentration of $0.22 \mathrm{~mm}$. However, the immunohistochemistry demonstrates that calretinin also occurs in supporting cells and auditory nerve terminals (Fig. 2). If calretinin were uniformly distributed in the sensory epithelium, which is $1000 \mu \mathrm{m}$ long, $100 \mu \mathrm{m}$ wide, and $60 \mu \mathrm{m}$ deep (Sneary, 1988; Hackney et al., 1993), with a total volume of $6 \mathrm{nl}$, the average cellular concentration would be $76 \mu \mathrm{M}$. This is still likely to be an overestimate because calretinin is also present in the surrounding cells of the cochlear duct (Fig. 2).

Immunofluorescence in cochlear whole mounts

Antibodies to each of the three calcium-binding proteins produced labeling throughout the turtle cochlea (Fig. 2). Within the auditory papilla, the main cell types are hair cells, supporting cells, and afferent and efferent nerve fibers (Sneary, 1988). Anti- bodies to calbindin-D28k labeled the hair cells but not the supporting cells. In contrast, antibodies to calretinin labeled the hair cells most prominently but also produced some signal in the surrounding supporting cells and in the nerve fibers. The pattern of labeling with the antibody to parvalbumin-3 was similar to that for calbindin-D28k, but no labeling was evident with the antibody to parvalbumin- $\alpha$. Calbindin-D28k and calretinin are $\sim 59 \%$ identical at the amino acid level in chickens, and there is possible cross reactivity (SWant product description) for the polyclonal anti-calbindin-D28k to calretinin. Furthermore, a SWant monoclonal anti-calbindin-D28k was found to be ineffective on both immunoblots of turtle brain tissue and on cochlear sections. It was therefore important to perform preadsorption controls. Preadsorption of anti-calbindin-D28k with calretinin had no effect on the appearance of label in the hair cells, but preadsorption with calbindin-D28k totally abolished the signal (data not shown). Similarly, preadsorption of the monoclonal anti-calretinin with calbindin-D28k did not alter the pattern of labeling. Preadsorption of anti-calretinin with calretinin abolished the fluorescence in all cochlear cells, indicating that the diffuse fluorescence in Figure $2 C$ is not background but rather reflects specific labeling. Other preadsorption controls, particularly for parvalbumin, are reported later in presentation of the electron microscopic data. These results support the notion that
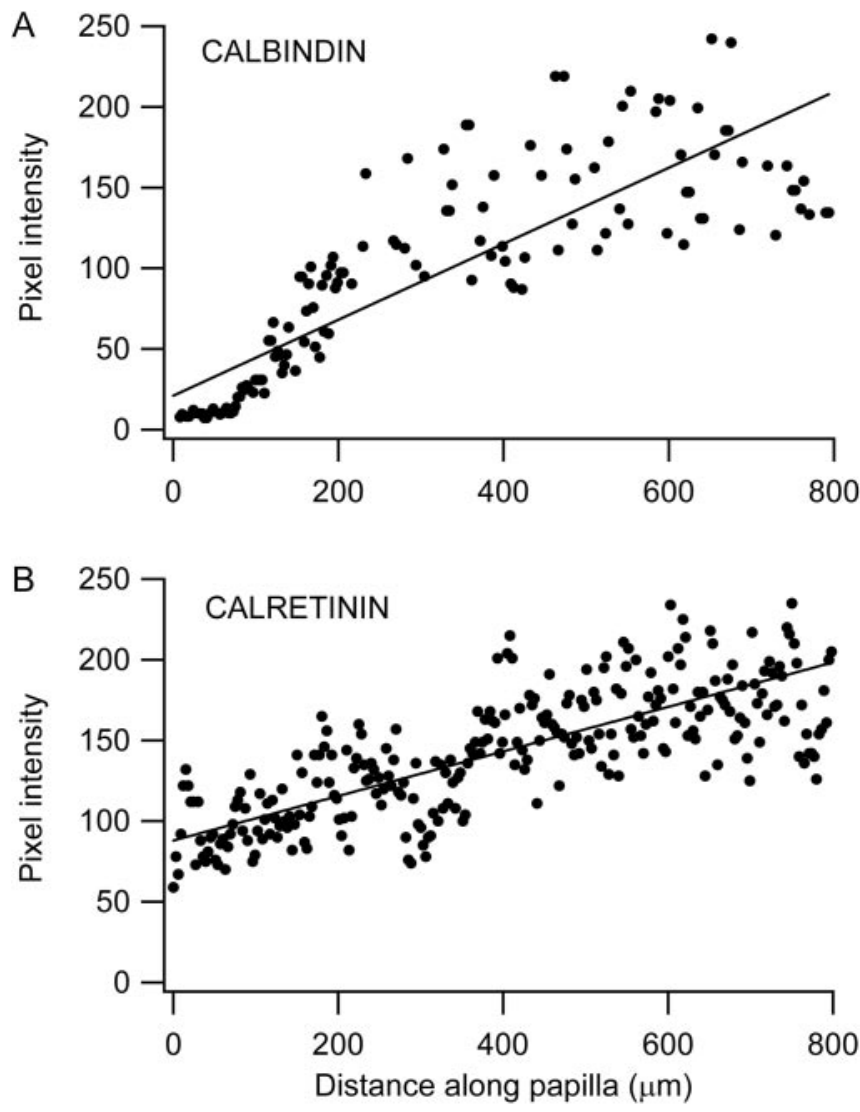

Figure 3. Gradients of immunofluorescence for calcium-binding proteins in the turtle cochlea. $A$, Calbindin-D28k; line is least-squares fit with $r=0.76$. $B$, Calretinin; line is leastsquares fit with $r=0.78$. In each plot, the ordinate denotes fluorescence intensity of pixels on a line along the center of the papilla drawn from apex to base. The pixel size was $3 \times 3 \mu \mathrm{m}$ and was less than the area of an individual hair cell or supporting cell. For the calbindin-D28k plot, only hair-cell measurements are shown as the immunofluorescence of the supporting cells was very small (see Fig. $2 \mathrm{~A}$ ). For the calretinin plot, the immunofluorescence gradient reflects both hair cells and supporting cells, which were comparably labeled (Fig. 2C). 


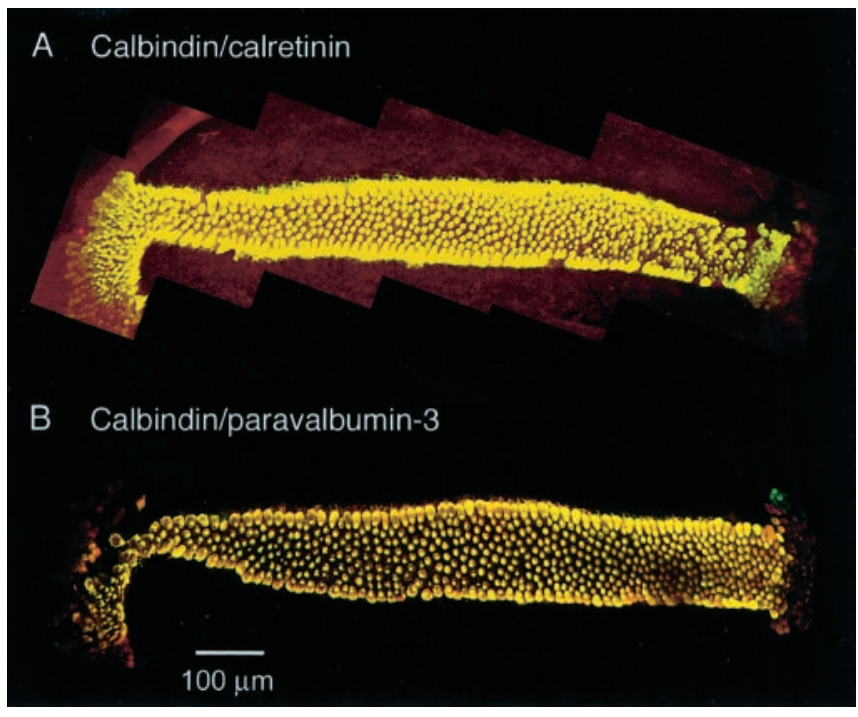

Figure 4. Colocalization of calcium-binding proteins in turtle cochlear whole mounts from double labeling with pairs of antibodies. A, Calbindin-D28k-calretinin. Superimposed images of polyclonal anti-calbindin-D28k FITC fluorescence and monoclonal anti-calretinin TRITC fluorescence. Hair cells on the basilar membrane are labeled with both green FITC and red TRITC. Note the red background between the hair cells, indicating the presence only of calretinin in the supporting cells. B, Calbindin-D28k-parvalbumin-3. Superimposed images of polyclonal anticalbindin-D28k FITC fluorescence and polyclonal anti-parvalbumin-3 TRITC fluorescence. The cochlea was first treated with rabbit anti-calbindin-D28k and incubated in anti-rabbit lgG-FITC secondary antibody; the tissue was then refixed in $4 \%$ paraformaldehyde, incubated in antiparvalbumin-3, and labeled with anti-rabbit lgG-TRITC secondary. Note the red hair cells at the low-frequency end to the right, indicating a lower concentration of calbindin-D28k. Similar images were obtained by first labeling with anti-parvalbumin-3, refixing, and then labeling with anti-calbindin-D28k. Both $A$ and $B$ are montages of six images acquired with $60 \times$ objective.

both calbindin-D28k and calretinin are present in the cochlea. In preparations labeled with calbindin-D28k and calretinin, but not with parvalbumin, there was evidence for a gradient in the immunofluorescence from the low- to high-frequency end of the cochlea (Fig. 2), suggesting a higher concentration of calcium buffer toward the high-frequency end. Quantification of the immunofluorescence gradient is shown for calbindin-D28k and calretinin in Figure 3.

Double-labeling experiments were performed to determine whether the different calcium-binding proteins were colocalized. These were most straightforward in experiments in which different secondary antibodies could be used: an anti-rabbit IgG-FITC for the polyclonal and anti-mouse IgG-TRITC for the monoclonal. The results showed that the same set of hair cells labeled with FITC-tagged anti-calbindin-D28k were also labeled with TRITC-tagged anti-calretinin (Fig. 4A). Superposition of the FITCand TRITC images produced yellow staining of the hair cells on the basilar membrane, indicating the presence of both proteins. Examining the codistribution of calbindin-D28k and parvalbumin-3 was more complicated because both were labeled with rabbit polyclonal antibodies. This necessitated refixing the tissue after incubating with one primary and secondary combination before treating with the other primary and secondary (see Materials and Methods). Similar results were obtained whether anti-calbindin-D28k or anti-parvalbumin-3 was applied first, and these showed that calbindin-D28k and parvalbumin-3 were also colocalized to the same hair cells on the basilar membrane (Fig. 4B).

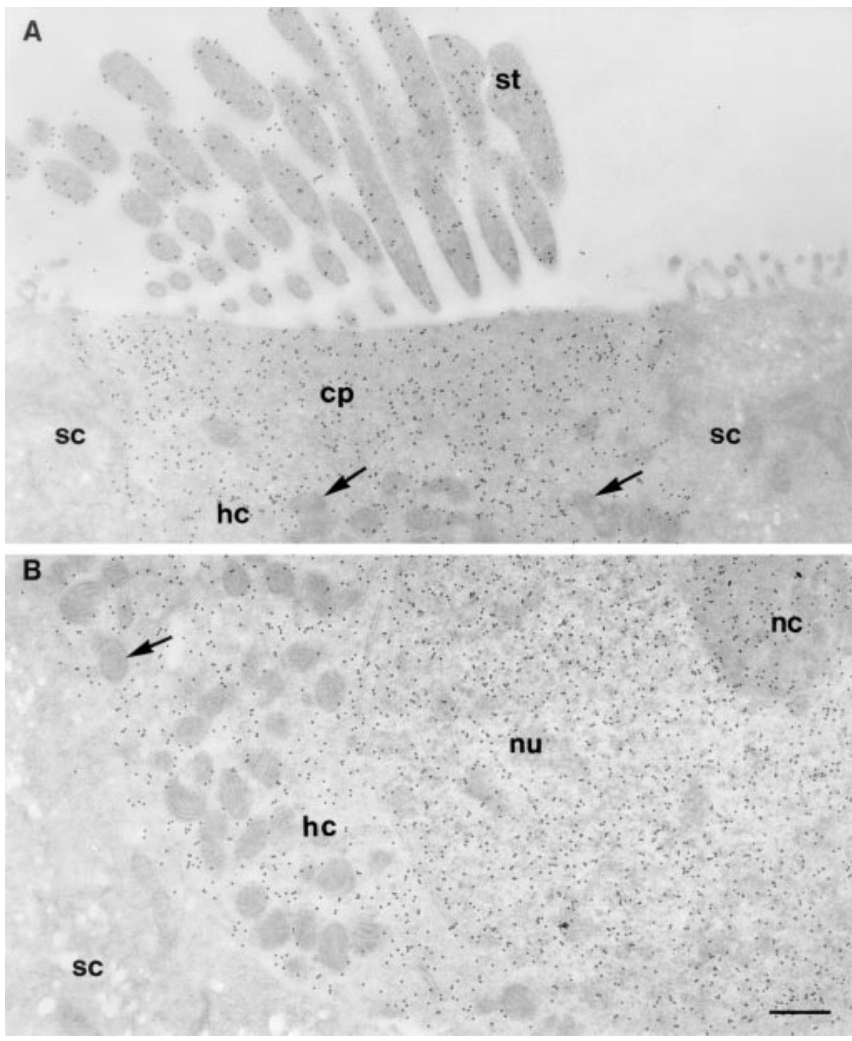

Figure 5. Post-embedding immunogold labeling for calbindin-D28k in turtle auditory papilla. A, Section through the apex of a hair cell (hc) and adjacent supporting cells (sc). Note the labeling of the stereocilia (st), cuticular plate (cp), and hair-cell cytoplasm but relative lack of labeling in the mitochondria (examples at arrows) and adjacent supporting cells (sc). B, Section through the basal region of a hair cell (hc) and adjacent supporting cell (sc). Note labeling of the nucleus (nu), nucleolus (nc), and hair-cell cytoplasm but lack of labeling in the mitochondria and adjacent supporting cell (sc). Scale bar, $0.5 \mu \mathrm{m}$.

\section{Post-embedding immunogold labeling}

High-resolution electron microscopy corroborated the cellular distribution of the calcium-binding proteins inferred from the light microscopy. Labeling for calbindin-D28k was confined to the hair cells (Figs. 5, 6) but was present for calretinin in both hair cells and supporting cells (Fig. 7). The calbindin-D28k labeling was unaffected by preadsorbing the antibody with calretinin but was completely abolished by preadsorbing with calbindin-D28k (data not shown). For calretinin, both the monoclonal antibody (SWant) and the polyclonal antibody (Chemicon) gave qualitatively similar results, but the latter produced a much higher density of immunogold that was preferable for quantification. The subcellular distribution of calbindin-D28k and calretinin within the hair cells was quite different. Calbindin-D28k labeling was dispersed throughout the cytoplasm, both above and below the nucleus, and was found in the cuticular plate and stereocilia. In the latter, the labeling was often stronger close to the plasma membrane (Fig. 6). Label was also found in the nucleus, in which it was slightly greater than in the neighboring cytoplasm. The relative amounts in different intracellular compartments were as follows: nucleus $\approx$ cuticular plate $>$ apical cytoplasm, stereocilia.

For calretinin, there was a small amount of label in the cytoplasm, but labeling was densest in the nucleus (Fig. 7). There was also a suggestion of specific localization to the apical membrane. Nerve terminals at the base of the hair cells were also labeled.

The pattern of labeling for parvalbumin-3 was very similar to that for calbindin-D28k and was confined to the hair cells, with 

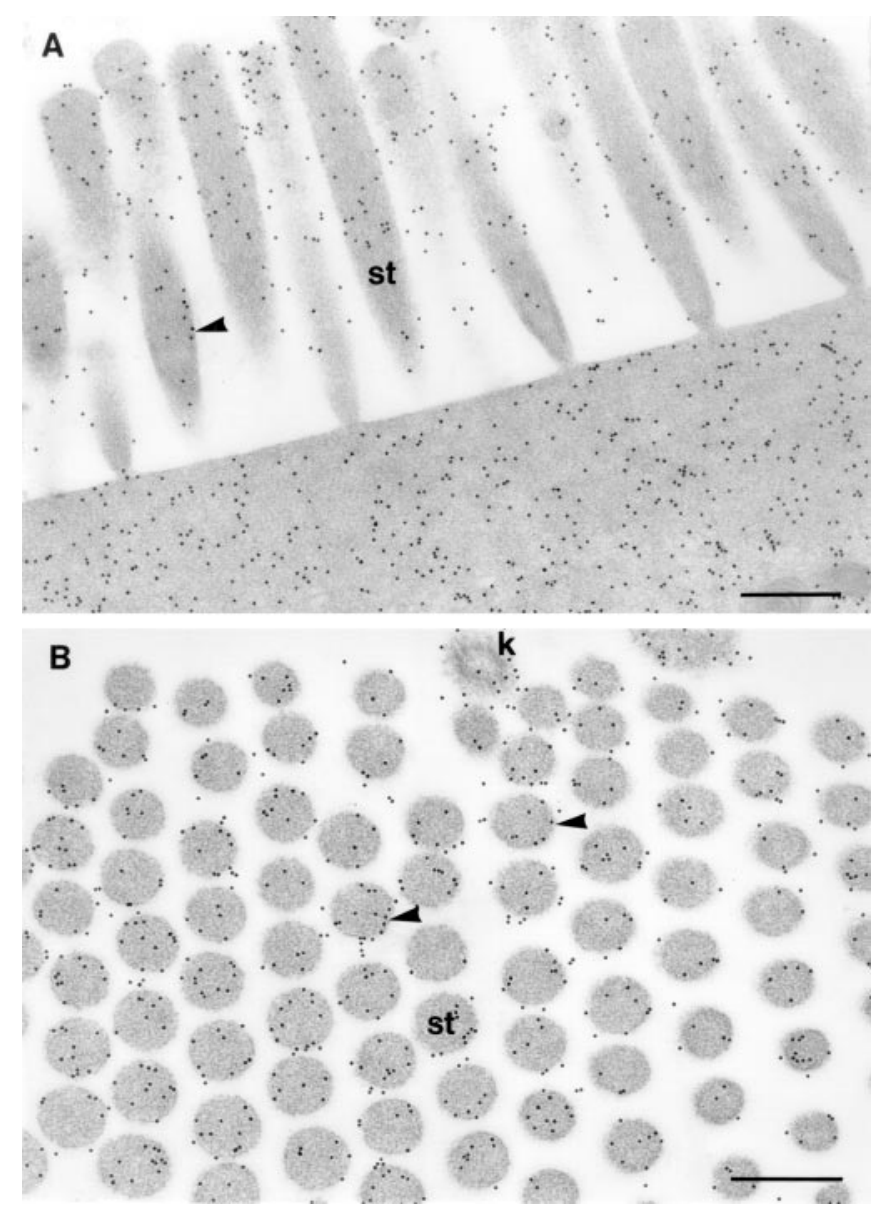

Figure 6. Immunogold labeling for calbindin-D28k in turtle hair bundle. Longitudinal $(A)$ and transverse $(B)$ section of a hair bundle. Note that labeling occurs in the stereocilia (st) and kinocilium ( $k$ ) and that there is some indication that stereociliary labeling is greatest toward their periphery (arrowheads), although this is not apparent in all profiles. Scale bars, $0.5 \mu \mathrm{m}$.

higher counts in the nucleus and cuticular plate than the cytoplasm (Fig. 8). Labeling of the stereocilia was more conspicuous than with calbindin-D28k, and, similar to calbindin-D28k, was marked around the edges of the stereocilia near the membrane (Fig. 8A). Cytoplasmic labeling was totally abolished by preadsorption of the antibody with parvalbumin-3 but was unaffected by preadsorption with parvalbumin- $\alpha$ (Fig. 9). Thus, the gold particles per field of view without and with preadsorption with parvalbumin- $\alpha$ were $30.4 \pm 4.4(n=20)$ and $29.1 \pm 4.9(n=20)$, respectively, in high-frequency cells and $30.7 \pm 7.2(n=20)$ and $25.2 \pm 4.2(n=20)$ in low-frequency cells. Because of the high concentrations of calbindin-D28k in turtle hair cells (see below), it was important to check that the parvalbumin-3 antibody was not showing any cross reactivity to this protein. Thus, the gold particles per field of view without and with preadsorption with calbindin-D28k were $23.5 \pm 5.5(n=15)$ and $25.7 \pm 7.9$ $(n=15)$, respectively. These are not significantly different, indicating that the parvalbumin-3 antibody is not recognizing calbindin-D28k.

For each of the proteins, the relative abundance of label was quantified (see Materials and Methods) by counting gold particles in three locations: the nucleus and apical cytoplasm of the hair cells and the supporting cells. Figure 10 gives plots of the gold particle counts as a function of hair-cell position within the cochlea. The collected results demonstrate the differential subcellular distributions of the three proteins and, at least for calbindin-
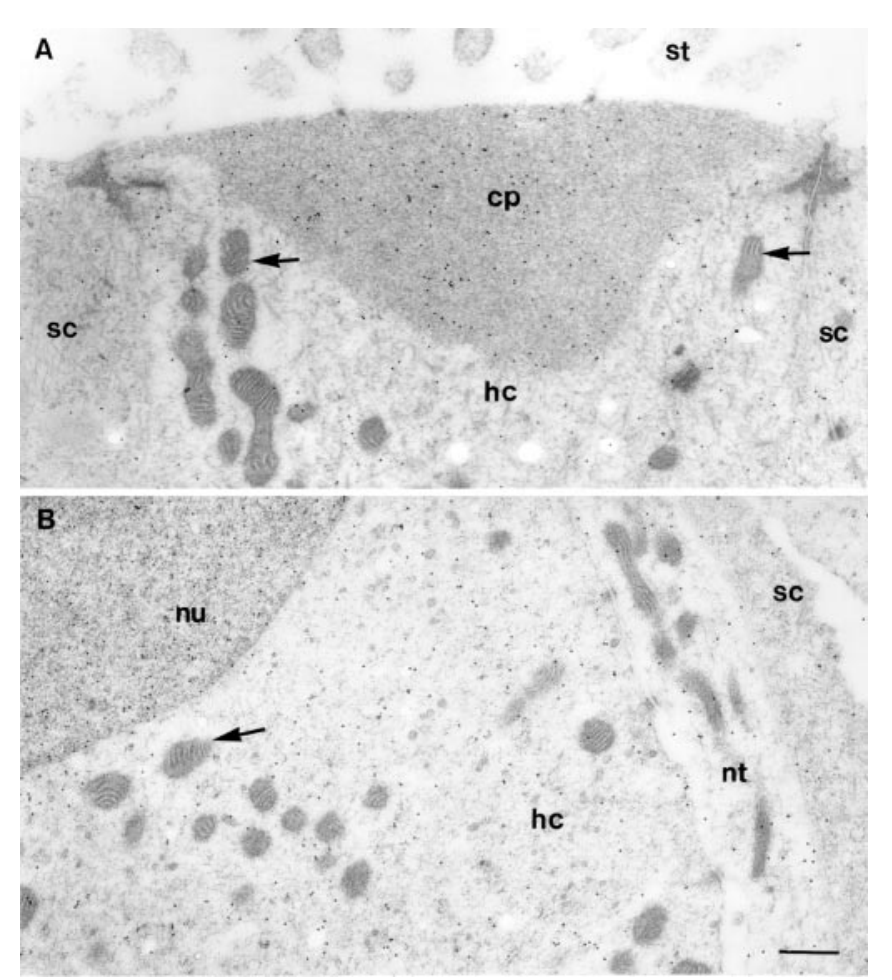

Figure 7. Post-embedding immunogold labeling for calretinin in turtle auditory papilla. A, Section through the apex of a hair cell (hc) and adjacent supporting cells (sc). Note the labeling of the stereocilia (st), cuticular plate (cp), and hair-cell cytoplasm but relative lack of labeling in the mitochondria (examples at arrows). Also note labeling in the cytoplasm of adjacent supporting cells (sc). B, Section through the basal region of a hair cell (hc) and adjacent nerve terminal (nt). Note that the nucleus (nu) is more heavily labeled than the hair-cell cytoplasm and note also the lack of labeling in the mitochondria. The nerve terminal and supporting cell (sc) are labeled. Scale bar, $0.5 \mu \mathrm{m}$.

D28k, provide evidence of a gradient in concentration along the cochlea, increasing toward the high-frequency end. No gradient was seen with either calretinin or parvalbumin-3.

\section{Concentrations of calcium-binding proteins}

Although all three calcium-binding proteins are found in turtle hair cells, the ability of any one to act as a calcium buffer will depend on its cytoplasmic concentration. To calculate a protein concentration from the gold particle counts, it was necessary to devise a method for calibrating the particle density. This was achieved by immunogold labeling a section of gel containing a known amount of protein for comparison with a cochlear section that was processed at the same time and in the same fluid drop. The method makes no assumption about the protein distribution and enables its concentration to be determined in different parts of the cell. The gel was formed from a solution of the protein in $10 \%$ BSA and PBS, fixed in $4 \%$ paraformaldehyde, and solidified by addition of $0.1 \%$ glutaraldehyde. The glutaraldehyde was needed to coagulate the solution but was not included in the original fixative because it reduces antibody labeling. For each protein, the counts in the standards were matched to hair-cell measurements made at an LF and an HF position in the cochlea, approximately one-third and two-thirds of the distance along the basilar membrane. The calculated concentrations of calbindinD28k in the apical cytoplasm (corrected for the 2.5-fold reduction in labeling of the standards caused by use of the glutaraldehyde fixative; see Materials and Methods) were $378 \pm 95 \mu \mathrm{M}(n=$ 10 ; HF $)$ and $187 \pm 64 \mu \mathrm{M}(n=10 ; \mathrm{LF})$. The equivalent cytoplas- 

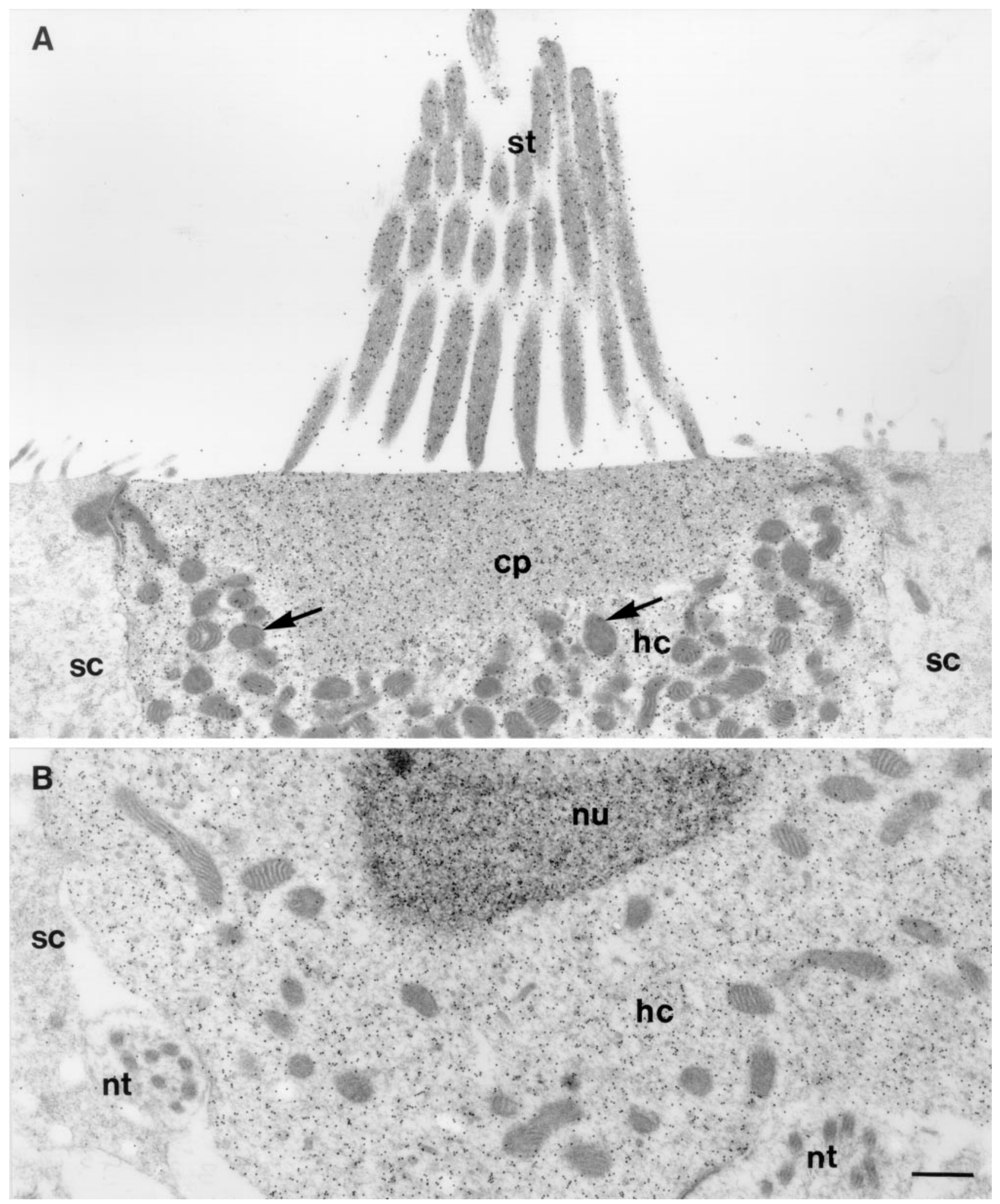

Figure 8. Post-embedding immunogold labeling for parvalbumin-3 in turtle auditory papilla. A, Section through the apex of a hair cell (hc) and adjacent supporting cells (sc). Note the labeling of the stereocilia (st), cuticular plate (cp), and hair-cell cytoplasm but relative lack of labeling in the mitochondria (examples at arrows) and adjacent supporting cells (sc). B, Section through the basal region of a hair cell (hc) and adjacent supporting cell (sc). Note labeling of the nucleus (nu) and hair-cell cytoplasm but lack of labeling in the adjacent supporting cell and nerve ending (nt). Scale bar, $0.5 \mu \mathrm{m}$.

mic values for calretinin, measured in the adjacent cochlear section, were $9 \pm 3 \mu \mathrm{M}(n=6 ; \mathrm{HF})$ and $11 \pm 2 \mu \mathrm{M}(n=10 ; \mathrm{LF})$. The gold particle counts in the nucleus were approximately fourfold larger than in the cytoplasm (Fig. 10), which implies a nuclear calretinin of $\sim 40 \mu \mathrm{M}$.
The predicted cytoplasmic concentrations for calbindinD28k were much higher than the $5 \mu \mathrm{M}$ standard in the gel, requiring a large and potentially inaccurate extrapolation. A second estimate was therefore obtained using a more concentrated 225 $\mu \mathrm{M}$ calbindin-D28k standard. This standard was processed and 


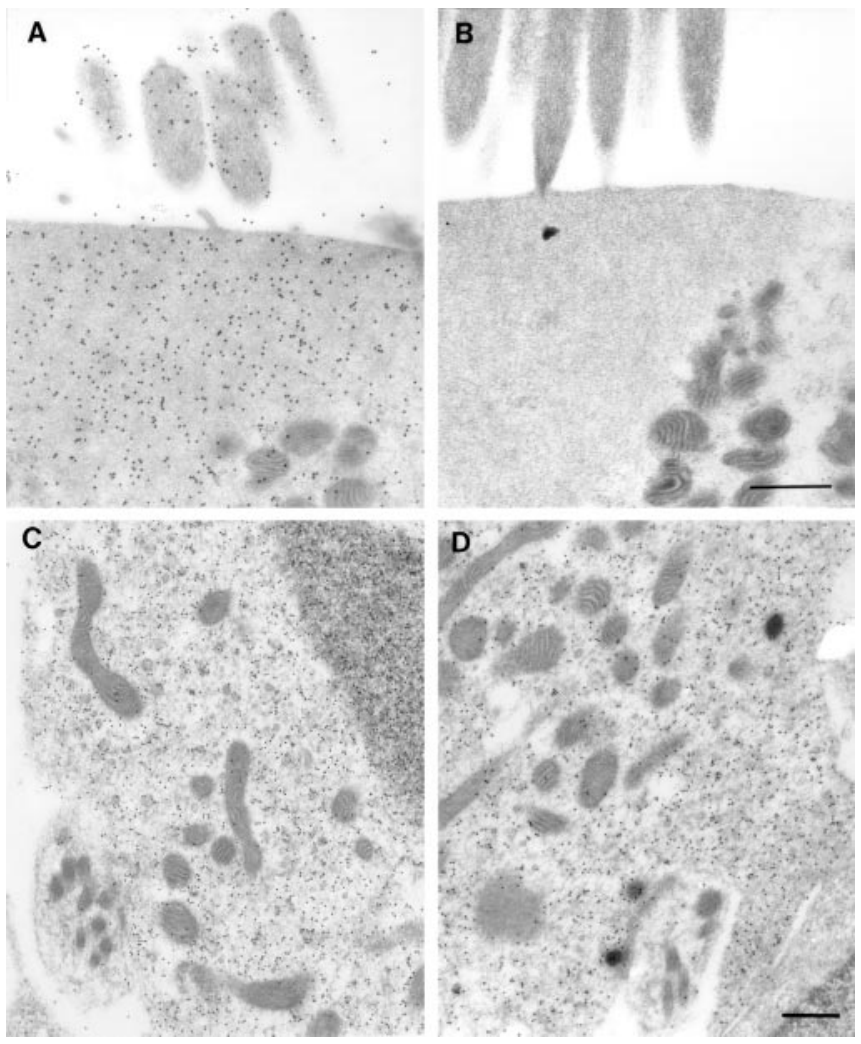

Figure 9. Preadsorption controls for parvalbumin-3 labeling of turtle auditory papilla. $A, B$, Hair-cell apices labeled simultaneously with the antibody to parvalbumin-3, either without $(A)$ or with $(B)$ preadsorption with parvalbumin-3. Note the virtual abolition of labeling after preadsorption with the protein. $C, D$, Hair-cell bases labeled simultaneously with the antibody for parvalbumin-3, either with or without preadsorption with rat parvalbumin- $\alpha$. Note that there is no effect of this preadsorption on the labeling. Scale bars, $0.5 \mu \mathrm{m}$. compared with tissue that had already been fixed in $4 \%$ paraformaldehyde plus $0.1 \%$ glutaraldehyde, thus avoiding the need to apply the glutaraldehyde correction. This second calibration gave a mean cytoplasmic calbindin-D28k of $129 \pm 95 \mu \mathrm{M}(n=20)$ for the low-frequency region and $627 \pm 151 \mu \mathrm{M}(n=20)$ for the high-frequency region. These values are in general accord with the initial measurements, confirming a calbindin-D28k concentration of several hundred micromolar, but the range is larger for the same cochlear positions.

The calibrations indicate that the cytoplasmic concentration of calbindin-D28k is $13-60$ times that of calretinin. This ratio is surprising given the prominent immunofluorescent labeling observed with the calretinin antibody, but it may reflect the greater efficiency of the calretinin antibody. Thus, from the immunoblots (Fig. 1), the polyclonal anti-calretinin (Chemicon) was approximately four times more effective than the polyclonal anticalbindin-D28k (SWant) for staining the same amount of protein. The number of gold particles per field of view, measured at the same magnification for the two antibodies, can be used to deduce the relative amounts of the two proteins if the numbers are corrected for the difference in the efficiency of labeling between the two antibodies. These give the ratio of cytoplasmic calbindin-D28k to calretinin as 18 (LF) and 51 (HF), which is similar to the values from the calibrations.

Immunogold counts of parvalbumin-3 in cochlear sections were also calibrated against known concentrations of the protein fixed in a gel processed at the same time and in the same fluid drop. After correcting for the attenuation in labeling caused by glutaraldehyde (see Materials and Methods), the concentrations of parvalbumin- 3 were $223 \pm 51 \mu \mathrm{M}(n=30)$ in the cytoplasm of hair cells at the LF end and $256 \pm 72 \mu \mathrm{M}(n=24)$ at the HF end. The fractional distances along the basilar membrane for these measurements were 0.2 (LF) and 0.75 (HF). These values indicate the presence of a substantial amount of parvalbumin-3, comparable with that of calbindin-D28k. However unlike calbindin-D28k, there was no difference in concentration between hair cells at the high- and low-frequency ends of the cochlea. Similar to the two other calcium-binding proteins, the concentration of parvalbumin-3 in the nucleus was at least twofold larger than in the cytoplasm (Fig. 10).

\section{Mammalian cochlea}

Parvalbumin-3 displays a strong sequence similarity to oncomodulin, a calciumbinding protein that has been reported to be present in mammalian outer hair cells (Sakaguchi et al., 1998). To confirm this observation and to examine the specificity of the frog anti-parvalbumin-3 antibody, we therefore studied the distribution of parvalbumin-3 labeling in the mammalian cochlea. Immunolabeling was found in both inner and outer hair cells showing a subcellular distribution identical to that observed in the turtle, with occurrence in both cell body and stereocilia (Fig. 11). The amount of label in the nucleus was two to three times that in the cytoplasm and stereocilia. Preadsorbing with the frog parvalbumin-3 protein to which the antibody was made abolished labeling

Figure 10. Distribution of immunogold labeling for calbindin-D28k $(A, B)$ parvalbumin-3 $(C)$, and calretinin (D). Gold particles per square micrometer were measured in longitudinal sections of the turtle auditory papilla in regions of the hair-cell nucleus ( $\mathrm{x}$ ), hair-cell cytoplasm (O), and supporting cell cytoplasm ( $\bigcirc)$. Lines are least-squares fits through sets of points. The calbindin-D28k plots indicate concentration gradients that are not evident with calretinin or parvalbumin. 


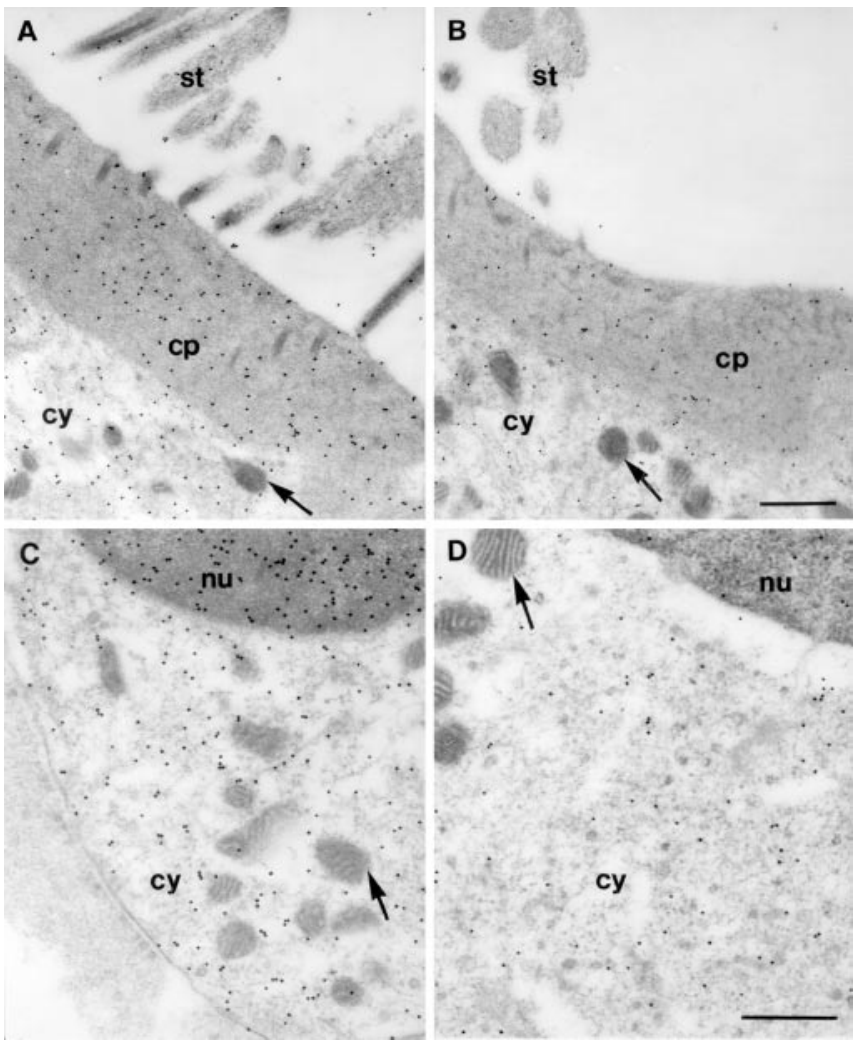

Figure 11. Immunogold labeling of guinea pig cochlear hair cells with the antibody for parvalbumin-3. $A, C$, Outer hair-cell apex and base, respectively; $B, D$, inner hair-cell apex and base, respectively. Note that the outer hair-cell stereocilia (st), cuticular plate (cp), and cytoplasm (cy) are all more heavily labeled than the same features in the inner hair cell and that the mitochondria (arrows) in both types of cell are not labeled. Scale bars, $0.5 \mu \mathrm{m}$.

on both inner and outer hair cells. Preadsorption with parvalbumin- $\alpha$ significantly reduced the signal in inner hair cells (Fig. 12) but not in outer hair cells. The gold particles per field of view of inner hair-cell cytoplasm without and with preadsorption with parvalbumin- $\alpha$ were (mean \pm 1 SEM) $6.6 \pm 0.5$ $(n=20)$ and $4.4 \pm 0.4(n=20)$, respectively, in the apical turn of the cochlea and $5.9 \pm 0.5(n=20)$ and $4.4 \pm 0.5(n=20)$ in the basal turn. Between one-quarter and one-third of the labeling in inner hair cells was thus removed by preadsorbing with parvalbumin- $\alpha$. The equivalent values in outer hair cells without and with preadsorption with parvalbumin- $\alpha$ were $16.3 \pm 1.9(n=20)$ and $16 \pm 1.8(n=20)$, respectively, in the apical turn and $15.2 \pm 1.3(n=20)$ and $16.4 \pm 1.8(n=20)$ in the basal turn. Thus, for outer hair cells, there was no significant difference before and after preadsorbing with parvalbumin- $\alpha$.

An explanation for these results is that the parvalbumin-3 antibody shows some cross reactivity to parvalbumin- $\alpha$. On this hypothesis, parvalbumin- $\alpha$ is present in inner but not outer hair cells, which agrees with previous observations by Pack and Slepecky (1995), who used a monoclonal antibody to parvalbumin- $\alpha$. However, both types of hair cell may also contain a protein related to parvalbumin-3, most likely oncomodulin. From the gold particle counts, the latter protein is nearly fourfold more concentrated in outer hair cells than in inner hair cells. Its presence in inner hair cells, albeit at a lower concentration, contrasts with the conclusion of Sakaguchi et al. (1998) that oncomodulin occurred only in outer hair cells. Our results show no convincing evidence for a tonotopic gradient in parvalbumin-3.

\section{Discussion}

\section{Concentrations of calcium-binding proteins}

The calcium-binding proteins calbindin-D28k, calretinin, and parvalbumin have all been proposed to act as intracellular calcium buffers, and all are present in turtle auditory hair cells. Labeling for calbindin-D28k and parvalbumin-3 was specific to hair cells, but labeling for calretinin was seen in hair cells, supporting cells, and nerve terminals. Molecular biological results indicated that the form of parvalbumin present in the turtle cochlea was identical to that in turtle muscle, which has been assigned to the parvalbumin- $\beta$ lineage (Maeda et al., 1984). The relationship between parvalbumin-3, against which the antibodies were raised, and parvalbumin- $\beta$ is described in Materials and Methods. Antibody labeling was quantified with post-embedding techniques that circumvent problems attributable to variability in cell permeabilization, which can hinder the interpretation of immunofluorescence methods. By comparing labeling in the cochlea with that of a standard containing a known amount of the calcium-binding protein, we estimated the concentrations of each of the proteins in the hair-cell cytoplasm. A similar calibration procedure was first used to determine the glutamate concentration in nerve terminals (Storm-Mathisen and Ottersen, 1990) but has not been applied previously to proteins. The method assumes that the solute is uniformly distributed throughout the gel and, more importantly, that the antibody recognizes the protein in the standard equally well to that in the tissue.

The calibrations were performed against recombinant frog parvalbumin-3, rat calbindin-D28k, and human calretinin because we did not have the equivalent turtle proteins. However, we cloned major portions of each protein from turtle and showed that turtle calbindin-D28k was $82 \%$ identical at the amino acid level to the rat version, and turtle calretinin was $91 \%$ identical to human over the $\mathrm{N}$-terminus region to which the antibodies were made. Turtle parvalbumin- $\beta$ was $62 \%$ identical to frog parvalbumin-3. The lack of identity may cause the cellular protein concentrations to be underestimated but is unlikely materially to alter the conclusion that the cytoplasmic concentrations of calbindin-D28k at $0.13-0.63 \mathrm{~mm}$ and parvalbumin- $\beta$ at $0.22-$ $0.26 \mathrm{~mm}$ are $>10$ times the concentration of calretinin. Assuming that calbindin-D28k has four $\mathrm{Ca}^{2+}$-binding sites and parvalbumin- $\beta$ has two (see below), our results indicate that the total concentration of cytoplasmic $\mathrm{Ca}^{2+}$-binding sites of these two proteins will be at least $1.0 \mathrm{~mm}$ in low-frequency hair cells and $3.0 \mathrm{~mm}$ in high-frequency cells.

Quantification of immunoblots was also used to derive concentrations of the calcium-binding proteins as $0.17 \mathrm{~mm}$ for calbindin-D28k and $0.20 \mathrm{~mm}$ for parvalbumin-3, assuming that these proteins are restricted to the hair cells. The values are similar to those inferred from the immunohistochemistry, but they represent an average concentration per cell and provide no insight about gradients within the cell or along the cochlea. This problem of immunoblot quantification is more serious for calretinin, which occurs in supporting cells and auditory nerve terminal as well as hair cells (Fig. 2). If calretinin were confined to the sensory epithelium, its mean cellular concentration would be $76 \mu \mathrm{M}$ (larger that the $40 \mu \mathrm{M}$ nuclear or $10 \mu \mathrm{m}$ cytoplasmic concentration inferred from the quantitative immunogold), but this is likely to be an overestimate because calretinin also occurs in the surrounding cells of the cochlear duct. 

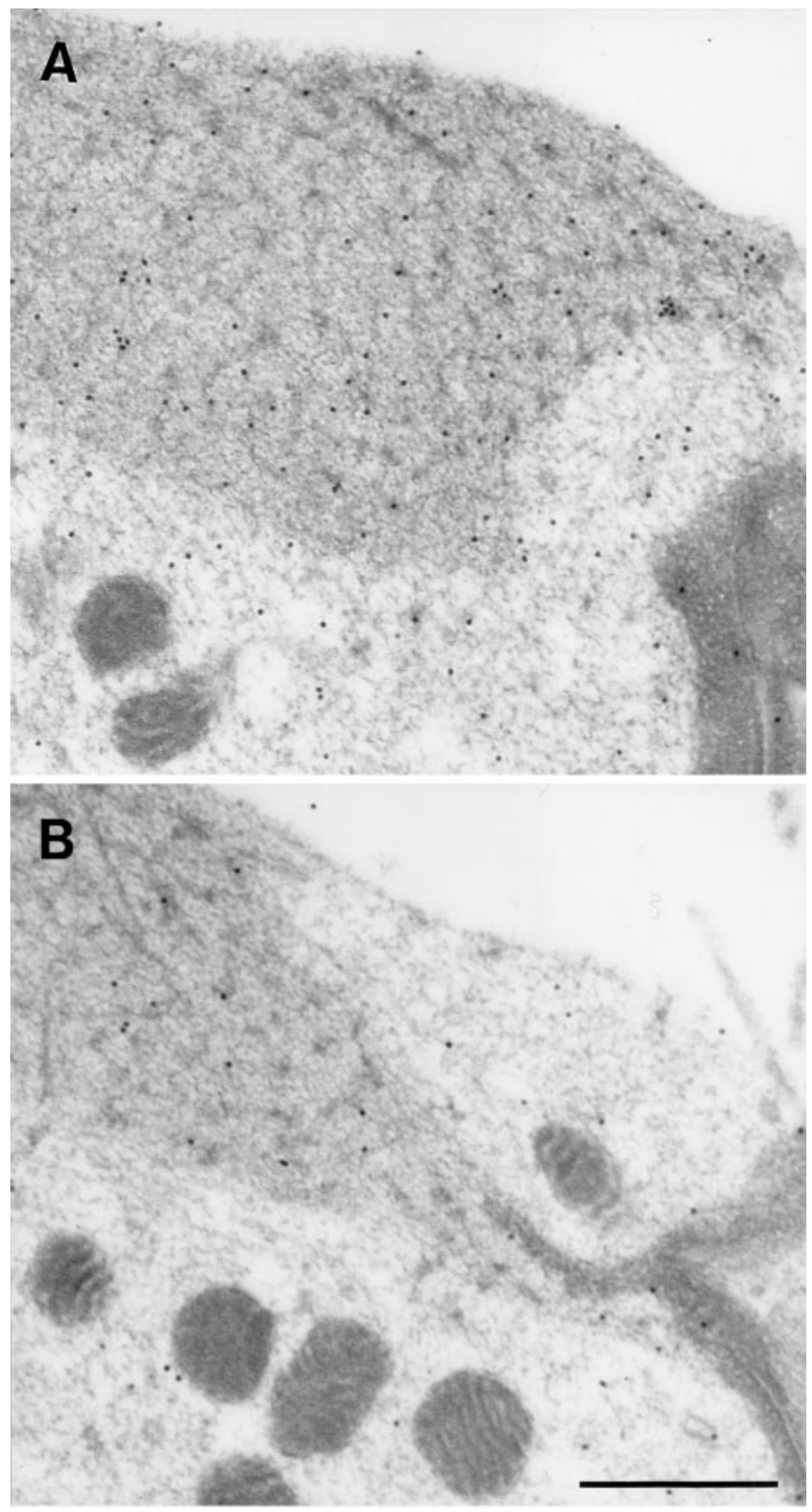

Figure 12. Immunogold labeling of guinea pig inner hair-cell apices with the antibody for parvalbumin-3 either without $(A)$ or with $(B)$ preadsorption with parvalbumin- $\alpha$. The labeling was reduced but not abolished after preadsorption with the protein. Scale bar, $0.5 \mu \mathrm{m}$.

\section{Role of calcium-binding proteins}

Calbindin-D28k and parvalbumin- $\beta$ differ in a number of respects that may be important for their role in calcium buffering. Parvalbumin- $\beta$ is less than one-half the molecular weight of calbindin-D28k and has only two calcium-binding sites compared with four in calbindin-D28k. Calcium-binding properties have been best characterized for calbindin-D28k, which has four low-affinity sites $\left(K_{\mathrm{D}}\right.$ of $\left.0.2-0.5 \mu \mathrm{M}\right)$, with fast binding kinetics $\left(k_{\mathrm{ON}}=1-8 \times 10^{7} \mathrm{M}^{-1} \cdot \mathrm{sec}^{-1}\right)$ and high selectivity for $\mathrm{Ca}^{2+}$ over $\mathrm{Mg}^{2+}$ (Nägerl et al., 2000). Of the two sites in parvalbumin- $\beta$, one is a low-affinity $\mathrm{Ca}^{2+}$-selective site $\left(K_{\mathrm{D}}\right.$ of $\left.\sim 0.08-0.8 \mu \mathrm{M}\right)$, as in calbindin-D28k. However, the other site has a significant affinity for $\mathrm{Mg}^{2+}$, which will compete with $\mathrm{Ca}^{2+}$, thereby slowing its binding kinetics and lowering its $\mathrm{Ca}^{2+}$ affinity (Pauls et al., 1996). Therefore, in the presence of physiological millimolar concentrations of $\mathrm{Mg}^{2+}$, both sites on parvalbumin- $\beta$ will have similar low affinity for $\mathrm{Ca}^{2+}$, but one site will bind $\mathrm{Ca}^{2+}$ rapidly, whereas the other will bind it slowly because it must first release $\mathrm{Mg}^{2+}$ (Pauls et al., 1996). Thus, the combination of calbindinD28k and parvalbumin- $\beta$ in turtle hair cells will contribute both fast and slow components to calcium buffering.

We measured the total concentration of cytoplasmic $\mathrm{Ca}^{2+}$ binding sites contributed by calbindin-D28k and parvalbumin- $\beta$ to be at least 1.0-3.0 mM. In comparison, physiological measurements (Ricci et al., 1998) indicate that the mobile buffer in turtle hair cells is equivalent to $0.1-0.4 \mathrm{~mm}$ BAPTA, which binds one $\mathrm{Ca}^{2+}$ per molecule. Those experiments measured buffer effects on mechanotransducer channel adaptation, which depend on calcium gradients near the channels. Such gradients vary with the product of $k_{\mathrm{ON}}$, the calcium-binding rate, and the buffer concentration (Naraghi and Neher, 1997). $k_{\mathrm{ON}}$ is not known for parvalbumin- $\beta$, but, for calbindin-D28k, the most recent measurements give $1-8 \times 10^{7} \mathrm{M}^{-1} \cdot \mathrm{sec}^{-1}$ (Nägerl et al., 2000). The two extremes are for each of two pairs of binding sites, and their average gives a $k_{\mathrm{ON}}$ for calbindin-D28k of $4.5 \times 10^{7} \mathrm{M}^{-1} \cdot \mathrm{sec}^{-1}$, approximately $1 / 10$ of that of BAPTA $\left(4 \times 10^{8} \mathrm{M}^{-1} \cdot \mathrm{sec}^{-1}\right)$. Assuming similar $k_{\mathrm{ON}}$ values for calbindin-D28k and parvalbumin- $\beta$, the $\mathrm{Ca}^{2+}$ buffering capacity of $0.1-0.4 \mathrm{~mm}$ BAPTA is therefore equivalent to $1-4 \mathrm{mM} \mathrm{Ca}^{2+}$-binding sites on the two proteins, concentrations not too different from the values inferred from immunohistochemistry. The results suggest that calbindin-D28k and parvalbumin- $\beta$ may together account for much of the cytoplasmic calcium buffering found in electrophysiological experiments. However, other calcium-binding proteins, such as calmodulin (Slepecky and Ulfendahl, 1993; Walker et al., 1993; Furness et al., 2002) and peptide 19 (Imamura and Adams, 1996), may also contribute to hair-cell calcium buffering.

That calbindin and parvalbumin are effective calcium buffers in vivo is shown by their ability to attenuate and slow calcium transients when expressed in dorsal root ganglion cells (Chard et al., 1993). Moreover, mice with a null mutation in the calbindinD28k gene possess ataxia associated with exaggerated calcium responses in cerebellar Purkinje cells (Airaksinen et al., 1997). Purkinje cells, like hair cells, contain substantial amounts of both calbindin-D28k (100-200 $\mu \mathrm{M})$ (Baimbridge et al., 1982) and parvalbumin $(45 \mu \mathrm{M})$ (Plogmann and Celio, 1993). Parvalbumin does not protect the cells from lack of calbindin-D28k, nor is it upregulated in the calbindin-D28k null mutant (Airaksinen et al., 1997). However, in mice with knock-outs of both calbindinD28k and parvalbumin- $\alpha$, the effects on Purkinje-cell morphology are more severe than in single knock-outs of either component alone (Vecelio et al., 2000). This suggests that both calciumbinding proteins are involved in regulating Purkinje-cell calcium. A similar situation may also exist in turtle hair cells.

What role does calretinin then play? Although it has been suggested to be the principal endogenous calcium buffer in frog saccular hair cells (Edmonds et al., 2000), its low cytoplasmic concentration and localization to the nucleus argue against this notion in the turtle. In pituitary neurons, calcium is compartmentalized into distinct cytosolic and nuclear pools (Hardingham et al., 1997), and the nuclear pool may be important for regulating gene expression (Mellström and Naranjo, 2001). Although calretinin occurs in inner hair cells in adult mice, during development, its expression in the outer hair cells is only transient, appearing first at the base of the cochlea and spreading toward the apex before disappearing at the onset of hearing 
(Dechesne et al., 1994). Thus, calretinin may have some distinct role associated with calcium buffering or signaling in the nucleus.

\section{Tonotopic gradients in calcium-binding proteins}

Our light-microscopic (Fig. 3) and electron-microscopic (Fig. 10) results both indicate a tonotopic gradient in the hair-cell concentration of calbindin-D28k. Immunocytochemistry has also revealed a gradient of calbindin-D28k in the cochleae of both mammals (Pack and Slepecky, 1995; Imamura and Adams, 1996) and birds (Hiel et al., 2001). In the turtle, the increase in calbindin-D28k concentration with CF correlates with the increased calcium influx through larger numbers of mechanoelectrical transducer channels (Ricci and Fettiplace, 1997) and voltage-dependent calcium channels (Ricci et al., 2000). The increase in calbindin-D28k concentration in the chick cochlea may also reflect an increase in the number of voltage-dependent calcium channels with CF (Martinez-Dunst et al., 1997). The calbindin-D28k gradients in turtle and chick auditory organs are opposite to that in the mammal, in which the calcium-binding protein is most concentrated at the low-frequency end of the cochlea (Pack and Slepecky, 1995; Imamura and Adams, 1996). If calbindin-D28k is a major calcium-binding protein in mammalian hair cells, it might be expected by analogy with the turtle that low-frequency hair cells have a higher calcium load than highfrequency hair cells. This implies a difference in calcium signaling between auditory hair cells of mammals and nonmammalian vertebrates. More information about the role of calbindin and other calcium-binding proteins in the mammalian cochlea might be obtained by additional quantitative immunogold experiments.

\section{References}

Airaksinen MS, Eilers J, Garaschuk O, Thoenen H, Konnerth A, Meyer M (1997) Ataxia and altered dendritic calcium signaling in mice carrying a targeted null mutation of the calbindin-D28k gene. Proc Natl Acad Sci USA 94:1488-1493.

Art JJ, Fettiplace R (1987) Variation of membrane properties in hair cells isolated from the turtle cochlea. J Physiol (Lond) 385:207-242.

Assad JA, Hacohen N, Corey DP (1989) Voltage dependence of adaptation and active bundle movements in bullfrog saccular hair cells. Proc Natl Acad Sci USA 86:2918-2922.

Baimbridge KG, Miller JJ, Parkes CO (1982) Calcium-binding protein distribution in the rat brain. Brain Res 239:519-525.

Baird RA, Steyger PS, Schuff NR (1997) Intracellular distributions of putative functions of calcium-binding proteins in the bullfrog vestibular otolith organs. Hear Res 103:85-100.

Chard PS, Bleakman D, Christiakos S, Fullmer CS, Miller RJ (1993) Calcium buffering properties of calbindin-D28k and parvalbumin in rat sensory neurones. J Physiol (Lond) 472:341-357.

Crawford AC, Evans MG, Fettiplace R (1989) Activation and adaptation of transducer currents in turtle hair cells. J Physiol (Lond) 419:405-434.

Dechesne CJ, Thomasset M (1988) Calbindin (CaBP-28kDa) appearance and distribution during development of the mouse inner ear. Dev Brain Res 40:233-242.

Dechesne CJ, Winsky L, Kim HN, Goping G, Vu TD, Wenthold RJ, Jacobitz DM (1991) Identification and ultrastructural localization of calretininlike calcium-binding protein (protein 10) in guinea pig and rat inner ear. Brain Res 560:139-148.

Dechesne CJ, Rabejac D, Desmadryl G (1994) Development of calretinin immunoreactivity in the mouse inner ear. J Comp Neurol 346:517-529.

Edmonds B, Reyes R, Schwaller B, Roberts WM (2000) Calretinin modifies presynaptic calcium signaling in frog saccular hair cells. Nat Neurosci 3:786-790.

Eybalin M, Ripoll C (1990) Immunolocalisation de la parvalbumine dans deux types de cellules glutamatergiques de la cochlée du cobaye: les cellules ciliées interné et les neurones du ganglion spiral. Compt Rend Acad Sci Paris 310:639-644.

Furness DN, Karkanevatos A, West B, Hackney CM (2002) An immunogold investigation of the distribution of calmodulin in the apex of cochlear hair cells. Hear Res 173:10-20.

Hackney CM, Fettiplace R, Furness DN (1993) The functional morphology of stereocilary bundles on turtle cochlear hair cells. Hear Res 69:163-175.

Hall JD, Betarbet S, Jaramillo F (1997) Endogenous buffers limit spread of free calcium in hair cells. Biophys J 73:1243-1252.

Hapak RC, Zhao H, Boschi JM, Henzl MT (1994) Novel avian thymic parvalbumin displays high sequence homology to oncomodulin. J Biol Chem 269:5288-5296.

Hardingham GE, Chawla S, Johnson CM, Bading H (1997) Distinct functions of nuclear and cytoplasmic calcium in the control of gene expression. Nature 385:260-265.

Heller S, Bell AM, Denis CS, Choe Y, Hudspeth AJ (2002) Parvalbumin 3 is an abundant $\mathrm{Ca}^{2+}$ buffer in hair cells. J Assoc Res Otolaryngol 3:488-498.

Hiel H, Navaratnam D, Oberholtzer JO, Fuchs PA (2001) Topological and developmental gradients of calbindin expression in the chick's inner ear. J Assoc Res Otolaryngol 3:1-15.

Imamura S, Adams JC (1996) Immunolocalization of peptide 19 and other calcium-binding proteins in the guinea-pig cochlea. Anat Embryol 194:407-418.

Jones EMC, Laus C, Fettiplace R (1998) Identification of $\mathrm{Ca}^{2+}$-activated $\mathrm{K}^{+}$channels splice variants and their distribution in the turtle cochlea. Proc R Soc Lond B Biol Sci 265:685-692.

Maeda N, Zhu D, Fitch WM (1984) Amino acid sequences of lower vertebrate parvalbumins and their evolution: parvalbumins of boa, turtle and salamander. Mol Biol Evol 1:473-488.

Mahendrasingam S, Furness DN, Hackney CM (1997) Ultrastructural localisation of cadherin in the adult guinea pig organ of Corti. Hear Res 111:85-92.

Mahendrasingam S, Furness DN, Hackney CM (1998) Ultrastructural localisation of spectrin in sensory and supporting cells of guinea pig organ of Corti. Hear Res 126:151-160.

Martinez-Dunst C, Michaels RL, Fuchs PA (1997) Release sites and calcium channels in hair cells of the chick cochlea. J Neurosci 17:9133-9144.

Mellström B, Naranjo JR (2001) Mechanism of $\mathrm{Ca}^{2+}$-dependent transcription. Curr Opin Neurobiol 11:312-319.

Moser T, Beutner D (2000) Kinetics of exocytosis and endocytosis at the cochlear inner hair cell afferent synapse of the mouse. Proc Natl Acad Sci USA 97:883-888.

Nägerl UV, Novo D, Mody I, Vergara JL (2000) Binding kinetics of calbindin-D28k determined by flash photolysis of caged $\mathrm{Ca}^{2+}$. Biophys J 79:3009-3018.

Naraghi M, Neher E (1997) Linearized buffered $\mathrm{Ca}^{2+}$ diffusion in microdomains and its implication for calculation of $\left[\mathrm{Ca}^{2+}\right]$ at the mouth of a calcium channel. J Neurosci 17:6961-6973.

Oberholtzer JC, Buettger C, Summers MC, Matchinsky FM (1988) The 28 $\mathrm{kDa}$ calbindin-D is a major calcium binding protein in the basilar papilla of the chick. Proc Natl Acad Sci USA 85:3387-3390.

Pack AK, Slepecky NB (1995) Cytoskeletal and calcium-binding proteins in the mammalian organ of Corti: cell type specific proteins displaying longitudinal and radial gradients. Hear Res 91:119-135.

Parsons TD, Lenzi D, Almers W, Roberts WM (1994) Calcium-triggered exocytosis and endocytosis in an isolated presynaptic cell: capacitance measurements in saccular hair cells. Neuron 13:875-883.

Pauls TL, Cox JA, Berchtold MW (1996) The $\mathrm{Ca}^{2+}$-binding proteins parvalbumin and oncomodulin and their genes: new structural and functional findings. Biochim Biophys Acta 1306:39-54.

Plogmann D, Celio MR (1993) Intracellular concentration of parvalbumin in nerve cells. Brain Res 600:273-279.

Ricci AJ, Fettiplace R (1997) The effects of calcium buffering and cyclic AMP on mechano-electrical transduction in turtle auditory hair cells. J Physiol (Lond) 501:111-124.

Ricci AJ, Wu Y-C, Fettiplace R (1998) The endogenous $\mathrm{Ca}^{2+}$ buffer and the time course of transducer adaptation in auditory hair cells. J Neurosci 18:8261-8277.

Ricci AJ, Gray-Keller M, Fettiplace R (2000) Tonotopic variations in calcium signalling in turtle auditory hair cells. J Physiol (Lond) 524:423-436.

Roberts WM (1993) Spatial calcium buffering in saccular hair cells. Nature 363:74-76. 
Roberts WM (1994) Localization of calcium signals by a mobile calcium buffer in frog saccular hair cells. J Neurosci 14:3246-3262.

Roberts WM, Jacobs RA, Hudspeth AJ (1990) Colocalization of ion channels involved in frequency selectivity and synaptic transmission at presynaptic active zones of hair cells. J Neurosci 10:3664-3684.

Rogers JH (1989) Two calcium-binding proteins mark many chick sensory neurons. Neuroscience 31:697-709.

Sakaguchi N, Henzl MT, Thalmann I, Thalmann R, Schulte BA (1998) Oncomodulin is expressed exclusively in outer hair cells in the organ of Corti. J Histochem Cytochem 46:29-39.

Slepecky NB, Ulfendahl M (1993) Evidence for calcium-binding proteins and calcium -dependent regulatory proteins in sensory cells of the organ of Corti. Hear Res 70:73-84.
Sneary MG (1988) Auditory receptor of the red-eared turtle. I. General ultrastructure. J Comp Neurol 276:573-587.

Storm-Mathisen J, Ottersen OP (1990) Immunocytochemistry of glutamate at the synaptic level. J Histochem Cytochem 38:1733-1743.

Tucker T, Fettiplace R (1996) Monitoring calcium in turtle hair cells with a calcium-activated potassium channel. J Physiol (Lond) 494:613-626.

Vecelio M, Schwaller B, Meye M, Hunziker W, Celio MR (2000) Alterations in Purkinje cell spines of calbindin-D28k and parvalbumin knock-out mice. Eur J Neurosci 12:945-954.

Walker RG, Hudspeth AJ, Gillespie PG (1993) Calmodulin and calmodulin-binding proteins in hair bundles. Proc Natl Acad Sci USA 90:2807-2811. 